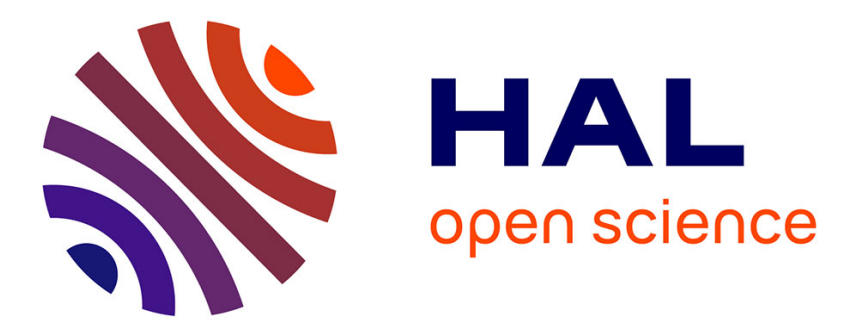

\title{
Urban and rural infant-feeding practices and health in early medieval Central Europe (9th-10th Century, Czech Republic)
}

Sylva Kaupova, Estelle Herrscher, Petr Veleminsky, Sandrine Cabut, Lumir Polacek, Jaroslav Brůžek.

\section{To cite this version:}

Sylva Kaupova, Estelle Herrscher, Petr Veleminsky, Sandrine Cabut, Lumir Polacek, et al.. Urban and rural infant-feeding practices and health in early medieval Central Europe (9th-10th Century, Czech Republic). American Journal of Physical Anthropology, 2014, 155, pp.635 - 651. 10.1002/ajpa.22620 . hal-01411012

\section{HAL Id: hal-01411012 \\ https://hal.science/hal-01411012}

Submitted on 8 Dec 2016

HAL is a multi-disciplinary open access archive for the deposit and dissemination of scientific research documents, whether they are published or not. The documents may come from teaching and research institutions in France or abroad, or from public or private research centers.
L'archive ouverte pluridisciplinaire HAL, est destinée au dépôt et à la diffusion de documents scientifiques de niveau recherche, publiés ou non, émanant des établissements d'enseignement et de recherche français ou étrangers, des laboratoires publics ou privés. 


\title{
Urban and Rural Infant-Feeding Practices and Health in Early Medieval Central Europe (9th-10th Century, Czech Republic)
}

\author{
Sylva Kaupová* ${ }^{1,2,3 *}$ Estelle Herrscher, ${ }^{1}$ Petr Velemínský, ${ }^{2}$ Sandrine Cabut, ${ }^{1}$ Lumír Poláček, ${ }^{4}$ \\ and Jaroslav Brư̌ek ${ }^{5}$ \\ ${ }^{1}$ Aix-Marseille Université, CNRS, Ministère de la culture et de la communication, LAMPEA UMR 7269, \\ 13094 Aix-en-Provence, France \\ ${ }^{2}$ Department of Anthropology, National Museum, Václavské náměstí 68, 11579 Praha 1, Czech Republic \\ ${ }^{3}$ Department of Anthropology and Human Genetics, Faculty of Science, Charles University in Prague, Viničná 7 , \\ 12844 Praha 2, Czech Republic \\ ${ }^{4}$ Institute of Archaeology of the Czech Academy of Science, Královopolská 147, 61200 Brno, Czech Republic \\ ${ }^{5}$ PACEA-A3P, UMR 5199, CNRS, Université Bordeaux 1, 33405 Talence, France
}

KEY WORDS breastfeeding; stable isotopes; morbidity; Middle Ages; Great Moravian
Empire

\begin{abstract}
In the Central European context, the 9th and 10th centuries are well known for rapid cultural and societal changes concerning the development of the economic and political structures of states as well as the adoption of Christianity. A bioarchaeological study based on a subadult skeletal series was conducted to tackle the impact of these changes on infant and young child feeding practices and, consequently, their health in both urban and rural populations. Data on growth and frequency of nonspecific stress indicators of a subadult group aged 0-6 years were analyzed. A subsample of 41 individuals was selected for nitrogen and carbon isotope analyses, applying an intra-individual sampling strategy (bone vs. tooth).
\end{abstract}

The period of weaning is associated with some of the main changes facing a child during the first years of life. The duration of exclusive breastfeeding, the timing and circumstances of the introduction of complementary food, and finally the cessation of breastfeeding have great potential to immediately affect the growth and health of an infant or child (Wilson et al., 2006; Kramer and Kakuma, 2009; Lamberti et al., 2011) as well as influence its development and future health, and physical wellbeing in the long term (McDade, 2005; Demmelmair et al., 2006; Haines and Kintner, 2008; Palou and Pico, 2009). The optimal timing of weaning is still largely discussed in terms of the so-called "weanling's dilemma" (Lutter, 1992): the choice between the known protective effect of exclusive breastfeeding against infectious morbidity, and the insufficiency of breast milk alone to satisfy the infant's energy and micronutrient (e.g., iron) requirements beyond a certain age (McDade and Worthman, 1998; Foote and Marriott, 2003; Wilson et al., 2006; Fewtrell et al., 2007; Kramer and Kakuma, 2009). While modern recommendations suggest that the optimal length of time for exclusive breastfeeding to be at most 6 months (WHO, 2002; Fewtrell et al., 2007; Kramer and Kakuma, 2009), the benefits of continuation of partial breastfeeding during the first 2 years of life has also been demonstrated (Prentice, 1991; Lamberti et al., 2011).

Infant feeding practices are highly variable, with the age of weaning adjusted to different environmental, cul-
The isotopic results attest to a mosaic of food behaviors. In the urban sample, some children may have been weaned during their second year of life, while some others may have still been consuming breast milk substantially up to 4-5 years of age. By contrast, data from the rural sample show more homogeneity, with a gradual cessation of breastfeeding starting after the age of 2 years. Several factors are suggested which may have been responsible for applied weaning strategies. There is no evidence that observed weaning strategies affected the level of biological stress which the urban subadult population had to face compared with the rural subadult population. Am J Phys Anthropol 155:635-651, 2014. 우 2014 Wiley Periodicals, Inc.

tural, and economic contexts (Fildes, 1995). The level of environmental risk may affect parental investment decisions, including breastfeeding and weaning of a child, parental effort being inversely associated with episodes of extreme stress such as famine and warfare. Parental effort also shows a quadratic association with pathogen stress, increasing as pathogen stress rises to moderate levels, but decreasing at higher levels (Quinlan, 2007). Economic or subsistence strategies that employ mothers away from the household or that expose them to a heavy workload in a tough environment can also adversely affect the duration of breastfeeding (Thorvaldsen, 2008;

Grant sponsor: Ministry of Culture of the Czech Republic; Grant numbers: DKRVO 2013/18 and DKRVO 2014/18; National Museum; 00023272; Grant sponsor: Charles University in Prague; Grant number: GA UK No. 642413; Grant sponsor: French-Czech project Barrande - Mobility; Grant number: 7AMB13FR012.

*Correspondence to: Sylva Kaupová; Department of Anthropology, National Museum, Cirkusová 1740, 19300 Praha 9, Czech Republic. E-mail: sylva_kaupova@nm.cz

Received 6 October 2013; accepted 9 September 2014

DOI: 10.1002/ajpa.22620

Published online 25 September 2014 in Wiley Online Library (wileyonlinelibrary.com). 
Nitsch et al., 2011). Moreover, there are cultural background factors, including medical, religious, and sexual ideas, that influence women's beliefs about optimal feeding practices (Fildes, 1995; Thorvaldsen, 2008; Yovsi and Keller, 2008). The adaptation of breastfeeding patterns to this external environment can lead to infant feeding practices that do not meet the infant's physiological needs and threaten its health, growth, and development (Fildes, 1995).

This enormous plasticity in weaning practices and its consequences, along with the development of new research methods on bone chemistry (Katzenberg et al., 1996), has attracted the attention of bioarchaeologists. Since the pioneering work of Katzenberg et al. (1996), which highlighted the utility of combining the isotopic results with osteological information, this approach is often used to determine the impact of infant and child nutrition and especially weaning practices on mortality (Schurr, 1997; Williams et al., 2005; Pearson et al., 2010; Howcroft et al., 2012) and morbidity (Prowse et al., 2008; Mays, 2010) patterns of specific populations. This study applies this approach to an early medieval, Great Moravian sample, representing a population from a stressful period of rapid cultural and social change (Poláček, 2008; Macháček, 2010).

\section{INFANT DIET AND STABLE ISOTOPE ANALYSES OF CARBON AND NITROGEN}

Nitrogen and carbon stable isotope ratios circulate in the biosphere through plants and animals. At each stage of the food chain, heavier isotopes are discriminated against, resulting in $\delta^{15} \mathrm{~N}$ and $\delta^{13} \mathrm{C}$ values that are $3 \%$ $5 \%$ and $1 \%$ heavier at each step, a phenomenon termed the "trophic level effect" (DeNiro and Epstein, 1978; DeNiro and Epstein, 1981; Minagawa and Wada, 1984; Schoeninger and De Niro, 1984; Ambrose and Norr, 1993).

At birth, the isotopic composition of a newborn's tissues is similar to those of the mother (Fogel et al., 1989). Once breastfeeding starts, infants derive their nutrition from their mother's protein, and due to the trophic level effect, they exhibit an elevation of both $\delta^{13} \mathrm{C}$ and $\delta^{15} \mathrm{~N}$ above maternal values. The isotopic values of tissues formed during the weaning process drops continuously with decreasing breast milk intake (Fogel et al., 1989; Fuller et al., 2006). According to Fuller et al. (2006), the $\delta^{13} \mathrm{C}$ values decline to maternal levels more rapidly than the $\delta^{15} \mathrm{~N}$ values, so that they can track the introduction of the first solid foods into the diet, whereas $\delta^{15} \mathrm{~N}$ values better reflect the length of breast milk consumption.

To examine potential intra-population variability in the duration of breastfeeding, we undertook a strategy of intra-individual sampling, which is to determine the feeding status of each infant (Eerkens et al., 2011; Waters-Rist et al., 2011). This approach has become increasingly common, taking samples from different mineralized tissues (Herrscher, 2003, 2013; Howcroft et al., 2012), from different parts of bone (Waters-Rist et al., 2011), or from serial sections of dental tissues (Fuller et al., 2003; Eerkens et al., 2011; Howcroft et al., 2012). This enables preservation of dietary information from different periods of an individual's life. Bone undergoes constant turnover, such that its isotopic composition reflects the average diet for some period before death. The length of this period is dependent on the bone turnover rate, and consequently is highly variable and affected by different factors such as sex, nutritional sta- tus, physical activity and especially the age of an individual (Martin and Armelagos, 1985; Seibel, 2003; Hedges et al., 2007). By contrast, dentine and enamel do not remodel, so their isotopic composition retains information regarding diet at the period of tooth development throughout life (Balasse et al., 1999; Richards et al., 2002). Therefore, once breastfeeding has started, the $\delta^{15} \mathrm{~N}$ of newly formed dental tissues reflects the full trophic level effect in a short time after the onset of breastfeeding, while the bone $\delta^{15} \mathrm{~N}$ increases gradually along with the growth of bone and replacement of prenatally developed tissue. During weaning, for the same reason, the dental $\delta^{15} \mathrm{~N}$ value drops much more rapidly to adult values (Herrscher, 2003). In our study, samples were taken from the bone at the mandibular border and from the apical end of the developing dental root, in which isotopic compositions reflect the diet immediately before death (with regard to a certain indeterminable period that the metabolic nitrogen pool takes to equilibrate with the diet) (Balasse et al., 2001).

With this approach, it is possible to estimate the nutritional status of a specific child on the basis of the relative nitrogen isotopic differences between tooth and bone samples $\left(\Delta^{15} \mathrm{Nt}-\mathrm{b}\right)$. A positive $\Delta^{15} \mathrm{Nt}-\mathrm{b}$ (higher $\delta^{15} \mathrm{~N}$ in tooth) suggests that the particular child was breastfed up to its time of death, a negative value (higher $\delta^{15} \mathrm{~N}$ in bone) indicates that weaning took place sometime before. However, it is necessary to recognize that: 1) weaning is not an abrupt change, but a continuous process starting with the first introduction of supplementary food and ending with the complete cessation of breastfeeding (Wilson et al., 2006; Pearson et al., 2010), and 2) using this sampling strategy, we are not able to distinguish these two exact moments of the child's life, so that our terms "breastfed" and "weaned" have to be interpreted with caution rather in the sense of "child still consuming breast milk substantially" and "child whose milk consumption decreased substantially.”

\section{HISTORICAL PERSPECTIVES AND AIMS OF THE STUDY}

The era of the Great Moravian Empire (9th to beginning of 10th century $\mathrm{AD}$ ) is a crucial period in the history of Central Europe, where the basis of the first Slavic state formation occurred (Fig. 1). The rapid development of the proto-state structure along with Christianization which extended into Moravia no later than the beginning of the 9th century, brought profound change to Moravian society. The introduction of the first urban centers brought new lifestyles to previously rural and tribal communities, while political consolidation encouraged increased socio-economic stratification of society (Poláček, 2008; Macháček, 2010; Herold, 2012).

Our understanding of how the above mentioned changes affected child care and how subadults responded to it is very limited. The timing of weaning with all its health, demographic, and others consequences has been, up to now, completely unknown in this population. It has not been possible for bioarchaeologists to study the impact of these changes in the lives and health of the Great Moravian inhabitants through direct comparison with pre-Great Moravian populations due to the cremation rite, which was widespread in this territory until the turn of the 8th and 9th centuries (Klanica, 1990; Měrínský, 2006). Therefore, an alternative approach to the study of this issue has been undertaken 

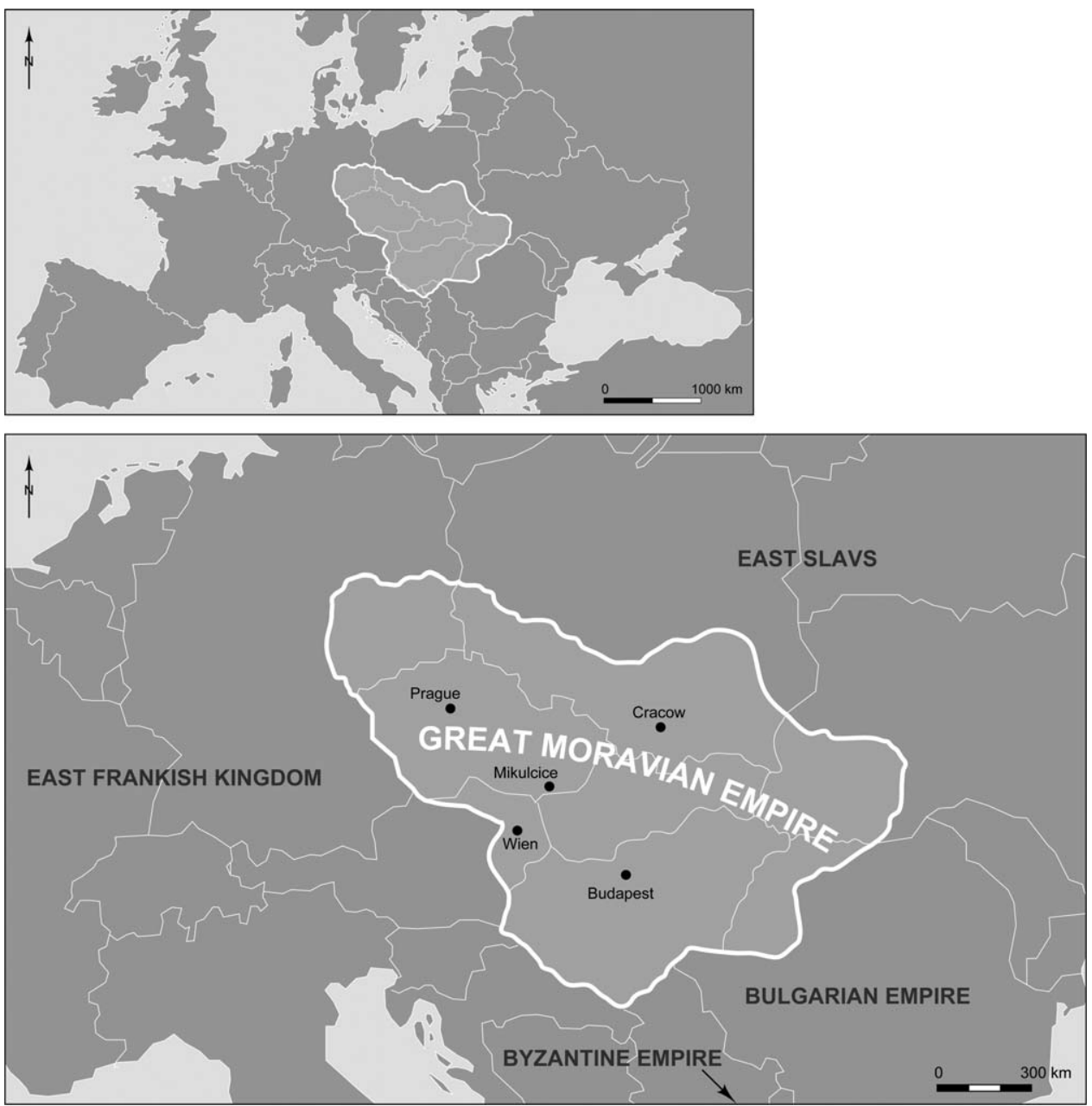

Fig. 1. Extension of Great Moravia and neighboring European empires in the latter third of the 9th century and the location of Mikulčice center, modified according to Poulík (1975) and Havelková et al. (2010).

in many anthropological studies (Trefný and Velemínský, 2008; Velemínský et al., 2009; Garcin et al., 2010; Havelková et al., 2010): a comparison of population samples of newly formed urban centers and those from rural sites. The rural sites are presumed to maintain an agricultural character, and the progress of Christianization as well as other societal changes were likely more gradual. In addition, strong foreign cultural influence is not supposed to be present in the rural environment.

This study aimed to explore potential differences in infant feeding practices between these two groups. Taking into account the early stage of urban formation (Poláček, 2008), one may hypothesize a shortening of the period of breastfeeding in the urban population due to the more rapid introduction of Christian taboos (Thorvaldsen, 2008). Consequently, potential differences in weaning strategies could be linked to differences in growth and health of infants and young children between samples of the urban and rural Great Moravian populations.

\section{MATERIAL AND METHODS Material}

The skeletal material came from three sites that are all located at the core of the Great Moravian state for- mation in the south-eastern tip of the today's Czech Republic (Fig. 1). The urban population sample comes from the Mikulčice settlement complex. Both the rural sites (Josefov and Prušánky) are located in an area of presumed hinterland that provided agricultural products to the growing Mikulčice center (Poláček, 2008).

Mikulčice. The agglomeration of the settlement complex in Mikulčice merged the attributes of a military fortress with those of an early urban formation. It is believed to be one of the prominent power centers of the Great Moravian Empire as well as an important center of Christianity in this territory (Poulík, 1970; Poláček, 2008).

The settlement complex consisted of the fortified center (including acropolis and the bailey), and a suburb, which gradually grew around the fortified core (Poláček and Marek, 1995; Poláček, 2008).

Archaeological research at Mikulčice has been going on for over 50 years. More than 2500 graves have been uncovered, both in the suburbs and the acropolis, dated to the 9th and the first third of the 10th century. The presence of elites of Great Moravian society is supported by the findings of graves (apparently dynastic) in the main church premises and the concentration of richly equipped graves (Poláček and Marek, 1995; Poláček, 2008). 
In this study, attention was paid to the subadult population buried at the acropolis, which is thought to be a residential area of the privileged class. In regards to the preservation of skeletal material, the individuals from all cemeteries within the acropolis were considered as one unit, neglecting potential slight temporal differences in the use of particular burial sites within the 9th century.

Josefov. This site, situated $7 \mathrm{~km}$ from Mikulčice center, is considered to be an example of a "poorer" rural Great Moravian burial site. During the excavation in 19571962, a total of 171 graves with the skeletal remains of 178 individuals were uncovered. The majority of the graves contained grave goods, typically a simple inventory (especially ceramics) with a less distinctive evidence of social stratification (Klíma, 2007; Poláček, 2008).

Prušánky I. The site Prušánky I is located $9.5 \mathrm{~km}$ from Mikulčice. Over the course of a number of excavations, a total of 376 graves were uncovered. According to the grave goods, the social stratification seems to be slightly higher than is the case of Josefov (Klanica, 2006).

A total of 144 individuals from the area of the Mikulčice castle, and another 158 individuals from rural cemeteries (Josefov and Prušánky), whose age at death was estimated to be less than 6 years, were included in the study. Whereas health investigations were conducted on the whole sample of subadults; for the isotopic study, 23 individuals from Mikulčice and 18 from Josefov were chosen. In the case of Josefov, the samples were taken from all the individuals whose state of preservation enabled sampling. In the case of Mikulčice, the subsample was selected to distribute the age classes and individuals with different quality of grave goods as equally as possible. The low state of preservation of skeletal material precluded the performance of stable isotope analysis on the sample from Prušánky.

\section{Methods}

Age-at-death estimation. Age-at-death estimates were obtained using the dental ageing method developed by Liversidge et al. (1998). In several cases, where this method was not applicable, the standards published by Moorrees et al. (1963) tabulated by Smith (1991) were used.

Isotopic analysis. At least $50 \mathrm{mg}$ of tooth dentine was sampled from the tip of the developing dental root at stage $R_{1 / 4}-\mathrm{Ap}_{1 / 2}$, after Smith (1991). The samples were taken from different tooth types, regarding the age-atdeath. Where possible, the first or second deciduous molar was sampled. From the youngest individuals with insufficiently developed roots of molars, canines or incisors were used. In some of these cases, two teeth had to be sampled to obtain a sufficient amount of dentine. Additionally, $80 \mathrm{mg}$ of mandibular bone of each individual was sampled. Due to the intra-individual variability in the root dentine formation rate between both different teeth and different developmental stages within a single tooth (Dean, 2007; Dean and Vesey, 2008), our dentine samples may represent slightly different periods of time. This, however, does not affect the results of our study, where the values of "most recent" (dentine) and "some period prior to death" (bone) samples are compared.

Collagen extraction proceeded according to the Longin (1971) method, modified by Bocherens (1992). Elemental analyses were performed on a Europa Scientific EA elemental analyzer connected to a Europa Scientific 20-20 IRMS for the carbon and nitrogen isotopes analysis at Iso-Analytical Limited, Crewe (UK). The uncertainty of isotopic measurements calculated on different standard replicates (IA-R042, IA-R045, IA-R046 and IA-R05, IAR06) was less than $0.1 \%$ for both nitrogen and carbon. A feeding status through $\Delta^{15} \mathrm{Nt}$-b was considered as a threshold for significance if the value was more than $0.4 \%$. This value is considered adequate in the light of the measurement precision as well as the stochastic isotopic variation reported by other studies $(\sim 0.3 \%$ ) (Chisholm, 1989; Katzenberg and Lovell, 1999). The children with a $\Delta^{15} \mathrm{Nt}$-b value higher than 0.4 were regarded as "breastfed," those with a $\Delta^{15} \mathrm{Nt}-\mathrm{b}$ value lower than -0.4 as "weaned."

Morphological analysis. To evaluate the effect of the urban/rural residency on health and physical well-being, the presence of cribra orbitalia, porotic hyperostosis, and endocranial lesions were evaluated macroscopically. The precise etiology of these skeletal lesions is not completely understood (Lewis, 2004; Wapler et al., 2004; Walker et al., 2009), but despite this fact, they are routinely used in studies of child morbidity as non-specific indicators of stress (e.g., Larsen, 1997; Bennike et al., 2005; Lewis, 2010, 2013; Gowland and Western, 2012). The presence of cribra orbitalia and porotic hyperostosis were noted, according to the scheme developed by Nathan and Haas (1966). However, for statistical analysis, the stage of lesion was not considered and all cases were counted as "Present." Some previous work on the topic (e.g., Bennike et al., 2005; Lewis, 2013) has considered the "Grade a" lesions to be: 1) too mild to represent serious health problems, and 2) easily mistaken for postmortem changes. Therefore, the statistical analysis was performed also for modified datasets (where just Grades $\mathrm{b}$ and $\mathrm{c}$ were considered pathological). The presence of endocranial lesions were evaluated according to the criteria proposed by Lewis (2004), but again, the type of lesion was not considered for statistical analyses. Because Lewis suggests rapid growth to be a complicating factor in the youngest individuals, the statistical tests were repeated, removing all individuals up to 1 year of age from the analysis. Additionally, growth was compared in children of differing residency types. It is well known that lower height for age and slowed maturation in a given population are associated with malnutrition, disease, and physiological stress (Eveleth and Tanner, 1990; Larsen, 1997). Diaphyseal length, anteroposterior (AP) and medio-lateral (ML) diameter at the midshaft of femur, tibia and humerus were measured to monitor both endochondral and appositional growth (Mays et al., 2009).

Statistical analysis. To establish a potential difference in weaning strategies between the two subgroups of the Great Moravian population, simple and multiple logistic regressions, and the subsequent Wald test, were performed to evaluate the effect of age (median age) and type of residency on the presence of breastfed/ 
TABLE 1. Collagen preservation data

\begin{tabular}{|c|c|c|c|c|c|c|c|c|}
\hline \multirow[b]{2}{*}{ Site and individual number ${ }^{a}$} & \multicolumn{4}{|c|}{ Tooth } & \multicolumn{4}{|c|}{ Bone } \\
\hline & Yield (\%) & $\% \mathrm{C}$ & $\% \mathrm{~N}$ & $\mathrm{C}: \mathrm{N}$ & Yield (\%) & $\% \mathrm{C}$ & $\% \mathrm{~N}$ & $\mathrm{C}: \mathrm{N}$ \\
\hline MIK 1 & 16.4 & 39.8 & 14.4 & 3.2 & 15.9 & 38.3 & 13.6 & 3.3 \\
\hline MIK 2 & 11.2 & 41.3 & 15.1 & 3.2 & 13.5 & 40.0 & 14.2 & 3.3 \\
\hline MIK 3 & 20.5 & 36.6 & 13.3 & 3.2 & 17.2 & 39.1 & 14.2 & 3.2 \\
\hline MIK 4 & 19.5 & 38.9 & 14.1 & 3.2 & 14.0 & 39.7 & 14.3 & 3.2 \\
\hline MIK 5 & 22.1 & 33.3 & 12.0 & 3.2 & 13.9 & 36.7 & 13.2 & 3.2 \\
\hline MIK 6 & 9.7 & 36.7 & 13.2 & 3.2 & 17.0 & 39.0 & 14.0 & 3.2 \\
\hline MIK 7 & 23.0 & 35.1 & 12.7 & 3.2 & 15.6 & 39.3 & 14.3 & 3.2 \\
\hline MIK 8 & 11.2 & 35.4 & 12.7 & 3.2 & 13.3 & 40.4 & 14.5 & 3.2 \\
\hline MIK 9 & 21.8 & 36.3 & 12.9 & 3.3 & 16.1 & 37.1 & 13.2 & 3.3 \\
\hline MIK 10 & 12.4 & 34.2 & 12.2 & 3.3 & 14.7 & 38.1 & 13.5 & 3.3 \\
\hline MIK 11 & 12.7 & 39.4 & 13.9 & 3.3 & 17.6 & 38.4 & 13.4 & 3.3 \\
\hline MIK 12 & 19.8 & 38.0 & 13.6 & 3.2 & 17.9 & 39.0 & 13.8 & 3.3 \\
\hline MIK 13 & 4.5 & 33.5 & 12.0 & 3.2 & 5.6 & 38.5 & 14.0 & 3.2 \\
\hline MIK 14 & 4.8 & 30.8 & 10.8 & 3.3 & 8.7 & 37.4 & 13.4 & 3.2 \\
\hline MIK 15 & 21.7 & 42.2 & 15.2 & 3.2 & 18.4 & 40.1 & 14.4 & 3.2 \\
\hline MIK 16 & 22.4 & 38.1 & 13.3 & 3.3 & 18.2 & 35.6 & 12.7 & 3.2 \\
\hline MIK 17 & 4.3 & 30.8 & 11.0 & 3.2 & 11.8 & 38.4 & 13.8 & 3.2 \\
\hline MIK 18 & 20.9 & 35.1 & 12.6 & 3.2 & 18.6 & 34.4 & 12.3 & 3.2 \\
\hline MIK 19 & 20.0 & 32.9 & 11.8 & 3.2 & 17.6 & 34.4 & 12.3 & 3.3 \\
\hline MIK 20 & 5.3 & 32.3 & 11.5 & 3.2 & 16.2 & 37.9 & 13.5 & 3.2 \\
\hline MIK 21 & 21.5 & 35.9 & 12.9 & 3.2 & 12.6 & 33.4 & 12.0 & 3.2 \\
\hline MIK 22 & 19.6 & 35.0 & 12.7 & 3.2 & 19.8 & 39.9 & 14.4 & 3.2 \\
\hline MIK 23 & 20.8 & 38.7 & 14.0 & 3.2 & 18.5 & 39.6 & 14.2 & 3.2 \\
\hline JOS 2 & 22.9 & 37.3 & 13.3 & 3.3 & 17.8 & 37.2 & 13.5 & 3.2 \\
\hline JOS 3 & 21.7 & 40.6 & 14.3 & 3.3 & 20.2 & 42.2 & 15.0 & 3.3 \\
\hline JOS 4 & 3.6 & 35.4 & 11.7 & 3.5 & 5.9 & 40.4 & 13.6 & 3.5 \\
\hline JOS 5 & 18.2 & 40.7 & 14.8 & 3.2 & 13.3 & 37.8 & 13.2 & 3.3 \\
\hline JOS 6 & 14.2 & 37.9 & 13.2 & 3.3 & 10.5 & 39.0 & 13.6 & 3.3 \\
\hline JOS 7 & 21.4 & 33.5 & 11.9 & 3.3 & 11.9 & 39.3 & 13.7 & 3.3 \\
\hline JOS 8 & 18.1 & 41.1 & 14.8 & 3.2 & 17.3 & 34.9 & 12.4 & 3.3 \\
\hline JOS 9 & 19.4 & 39.1 & 14.1 & 3.2 & 17.9 & 42.5 & 15.0 & 3.3 \\
\hline JOS 10 & 21.6 & 36.3 & 13.1 & 3.2 & 22.5 & 36.4 & 13.2 & 3.2 \\
\hline JOS 11 & 18.5 & 39.1 & 14.1 & 3.2 & 17.4 & 39.8 & 14.3 & 3.2 \\
\hline JOS 12 & 19.8 & 38.6 & 13.9 & 3.2 & 15.2 & 39.9 & 14.3 & 3.2 \\
\hline JOS 13 & 13.9 & 42.6 & 15.4 & 3.2 & 16.5 & 39.0 & 13.9 & 3.3 \\
\hline JOS 14 & 17.7 & 39.8 & 14.3 & 3.2 & 17.7 & 37.7 & 13.5 & 3.2 \\
\hline JOS 15 & 23.3 & 35.0 & 12.4 & 3.3 & 17.5 & 34.3 & 12.0 & 3.3 \\
\hline JOS 16 & 7.6 & 32.2 & 11.5 & 3.3 & 17.7 & 41.3 & 14.8 & 3.2 \\
\hline JOS 17 & 12.1 & 39.5 & 14.1 & 3.2 & 18.8 & 41.3 & 14.7 & 3.3 \\
\hline JOS 18 & 18.8 & 41.2 & 14.7 & 3.2 & 10.0 & 40.8 & 14.4 & 3.3 \\
\hline JOS 20 & 18.7 & 40.8 & 14.8 & 3.2 & 19.9 & 42.1 & 15.1 & 3.2 \\
\hline
\end{tabular}

a JOS, Josefov; MIK, Mikulčice.

weaned status. The consideration of age in multiple regression permits the adjustment of the results for this variable. Moreover, the interaction between age and type of residency has been tested to determine if the potential age-related trends are similarly apparent in the both subsamples. In the case of data regarding the presence of non-specific stress indicators, the same type of analysis was used: simple and multiple logistic regressions taking into account the median age. To evaluate the influence of the type of residency on the growth in different skeletal dimensions, the method developed by Mays et al. (2009) was applied: a polynomial regression for each of the dependent variables (bone length, $\mathrm{AP}$ or ML) on dental age was fitted. This procedure enabled investigation of the differences in bone dimensions between urban and rural individuals, controlling for the effect of dental age by carrying out the analysis of the regressions' standardized residuals. Since these did not meet a normal distribution, the urban and rural differences were verified by a nonparametric test, the Wilcoxon test for independent data. The analysis was performed by the Statistica v7.0 and the SAS/STAT $®$ software v12.1.

\section{RESULTS AND DISCUSSION Isotopic results}

Data quality. All the samples met the criteria for good collagen preservation (DeNiro, 1985; van Klinken, 1999) (Table 1). All samples had an elemental compositions range from 30.8 to $42.6 \mathrm{wt} \%$ for carbon (mean \pm 10 ' equals $37.1 \pm 3.2$ for tooth samples; $38.6 \pm 2.2$ for bone samples) and from 10.8 to $15.4 \mathrm{wt} \%$ for nitrogen (13.3 \pm 1.2 for tooth; $13.7 \pm 0.8$ for bone). Their C:N ratios (ranging from 3.2 to 3.5 ) were compatible with well preserved collagen and the collagen yield was in all cases higher than $1 \%$. Several times, the collagen yield was surprisingly high $(20 \%-22 \%)$ but acceptable considering the proportionally higher collagen content in the subadult bone (Baker et al., 1946; Waters-Rist et al., 2011). 
TABLE 2. $\delta^{13} C, \delta^{15} N$ and their intra-individual differences with estimated feeding status

\begin{tabular}{|c|c|c|c|c|c|c|c|c|c|}
\hline \multirow{2}{*}{$\begin{array}{l}\text { Site and individual } \\
\text { number }\end{array}$} & \multirow{2}{*}{$\begin{array}{c}\text { Dental } \\
\text { age (years) }\end{array}$} & \multirow{2}{*}{$\begin{array}{l}\text { Sampled } \\
\text { tooth }^{\mathrm{b}}\end{array}$} & \multicolumn{3}{|c|}{$\delta^{13} \mathrm{C}$} & \multicolumn{3}{|c|}{$\delta^{15} \mathrm{~N}$} & \multirow{2}{*}{$\begin{array}{c}\text { Estimated } \\
\text { feeding status }\end{array}$} \\
\hline & & & Tooth & Bone & $\Delta^{13} \mathrm{Ct}-\mathrm{b}^{\mathrm{c}}$ & Tooth & Bone & $\Delta^{15} \mathrm{Nt}-\mathrm{b}^{\mathrm{c}}$ & \\
\hline MIK 1 & $0.4-0.8$ & $\mathrm{dm} 1$ & -18.4 & -18.2 & -0.2 & 14.8 & 14.0 & 0.8 & Breastfed \\
\hline MIK 2 & $0.9-1.3$ & $\mathrm{dc}$ & -14.2 & -15.4 & 1.1 & 15.0 & 13.7 & 1.4 & Breastfed \\
\hline MIK 3 & $0.7-1.1$ & di1, di2 & -14.5 & -15.6 & 1.1 & 17.9 & 16.6 & 1.3 & Breastfed \\
\hline MIK 4 & $1.3-1.7$ & dm1 & -18.2 & -17.9 & -0.3 & 12.3 & 13.2 & -0.9 & Weaned \\
\hline MIK 5 & $1.3-1.7$ & $\operatorname{di2}(2 x)$ & -17.9 & -18.2 & 0.3 & 13.0 & 12.4 & 0.7 & Breastfed \\
\hline MIK 6 & $1.8-2.2$ & $\mathrm{dm} 1$ & -17.5 & -17.6 & 0.2 & 13.1 & 12.9 & 0.2 & ND \\
\hline MIK 7 & $1.7-2.1$ & $\mathrm{dm} 1$ & -16.7 & -16.6 & -0.1 & 14.7 & 14.5 & 0.2 & ND \\
\hline MIK 8 & $1.1-1.5$ & $\mathrm{dm} 1$ & -16.8 & -17.2 & 0.4 & 19.2 & 18.6 & 0.6 & Breastfed \\
\hline MIK 9 & $1.9-2.3$ & $\mathrm{dm} 2$ & -17.7 & -17.4 & -0.3 & 12.1 & 12.9 & -0.7 & Weaned \\
\hline MIK 10 & $2.4-2.8$ & $\mathrm{dc}(2 \mathrm{x})$ & -16.8 & -17.8 & 1.0 & 11.5 & 10.7 & 0.9 & Breastfed \\
\hline MIK 11 & $2.6-3.0$ & $\mathrm{dm} 2$ & -15.4 & -15.3 & -0.1 & 11.9 & 11.3 & 0.6 & Breastfed \\
\hline MIK 12 & $2.3-2.7$ & $\mathrm{dm} 2$ & -16.9 & -17.5 & 0.6 & 12.6 & 12.4 & 0.2 & ND \\
\hline MIK 13 & $2.5-2.9$ & $\mathrm{dc}(2 \mathrm{x})$ & -16.9 & -17.2 & 0.3 & 12.2 & 12.3 & -0.2 & ND \\
\hline MIK 14 & $3.5-3.9$ & $\mathrm{dm} 2$ & -17.6 & -17.9 & 0.3 & 11.5 & 11.8 & -0.3 & ND \\
\hline MIK 15 & $2.2-2.6$ & $\mathrm{dm} 2$ & -17.3 & -17.5 & 0.2 & 12.6 & 11.7 & 0.9 & Breastfed \\
\hline MIK 16 & $2.8-3.2$ & $\operatorname{dm} 2$ & -17.5 & -17.3 & -0.2 & 11.7 & 11.7 & 0.0 & ND \\
\hline MIK 17 & $3.0-3.4$ & $\mathrm{dm} 2$ & -18.3 & -18.8 & 0.5 & 12.7 & 12.7 & -0.1 & ND \\
\hline MIK 18 & $3.8-4.2$ & $\mathrm{dm} 2$ & -17.6 & -17.9 & 0.3 & 12.4 & 11.8 & 0.5 & Breastfed \\
\hline MIK 19 & $4.3-5.5$ & $\mathrm{dm} 2$ & -17.9 & -17.1 & -0.9 & 11.4 & 12.1 & -0.8 & Weaned \\
\hline MIK 20 & $3.3-3.7$ & $\mathrm{dm} 2$ & -14.9 & -16.2 & 1.2 & 11.3 & 10.9 & 0.3 & ND \\
\hline MIK 21 & $4.1-4.5$ & $\mathrm{dm} 2$ & -18.5 & -18.7 & 0.3 & 12.0 & 11.6 & 0.5 & Breastfed \\
\hline MIK 22 & $3.0-3.4$ & $\mathrm{dm} 2$ & -17.5 & -17.7 & 0.1 & 11.6 & 10.9 & 0.7 & Breastfed \\
\hline MIK 23 & $5.0-5.4$ & $\mathrm{dm} 2$ & -18.8 & -18.7 & -0.1 & 11.2 & 10.9 & 0.2 & ND \\
\hline JOS 2 & $1.1-1.5$ & di1, di2 & -14.7 & -14.9 & 0.2 & 13.4 & 11.8 & 1.6 & Breastfed \\
\hline JOS 3 & $0.8-1.2$ & di1, di2 & -16.8 & -17.0 & 0.2 & 13.5 & 12.5 & 1.0 & Breastfed \\
\hline JOS 4 & $1.2-1.6$ & $\mathrm{dm} 1$ & -16.8 & -17.1 & 0.3 & 11.4 & 11.1 & 0.3 & ND \\
\hline JOS 5 & $1.1-1.5$ & $\operatorname{di2}(2 x)$ & -15.7 & -16.3 & 0.6 & 14.1 & 12.7 & 1.4 & Breastfed \\
\hline JOS 6 & $1.6-2.0$ & $\mathrm{dm} 1$ & -16.4 & -16.3 & -0.1 & 15.0 & 13.5 & 1.5 & Breastfed \\
\hline JOS 7 & $1.9-2.3$ & $\mathrm{dm} 1$ & -17.0 & -17.8 & 0.8 & 13.0 & 12.5 & 0.5 & Breastfed \\
\hline JOS 8 & $2.4-2.8$ & $\mathrm{dc}$ & -16.3 & -16.3 & 0.0 & 12.6 & 12.8 & -0.2 & ND \\
\hline JOS 9 & $1.8-2.2$ & $\mathrm{dm} 1$ & -17.3 & -17.8 & 0.5 & 11.1 & 10.5 & 0.5 & Breastfed \\
\hline JOS 10 & $2.3-3.7$ & $\operatorname{dm} 2$ & -16.0 & -16.2 & 0.2 & 11.6 & 11.0 & 0.7 & Breastfed \\
\hline JOS 11 & $2.0-2.4$ & $\mathrm{dm} 1$ & -16.6 & -17.0 & 0.4 & 12.6 & 11.7 & 0.9 & Breastfed \\
\hline JOS 12 & $2.6-3.0$ & $\mathrm{dm} 2$ & -16.8 & -17.1 & 0.3 & 12.9 & 12.9 & 0.0 & ND \\
\hline JOS 13 & $1.9-2.3$ & $\mathrm{dm} 2$ & -17.1 & -16.7 & -0.4 & 12.4 & 12.5 & -0.1 & ND \\
\hline JOS 14 & $2.5-2.9$ & $\mathrm{dm} 2$ & -18.0 & -18.7 & 0.7 & 12.2 & 11.3 & 0.9 & Breastfed \\
\hline JOS 15 & $2.5-2.9$ & $\mathrm{dm} 2$ & -17.4 & -16.2 & -1.2 & 13.2 & 14.0 & -0.8 & Weaned \\
\hline JOS 16 & $2.7-3.1$ & $\mathrm{dm} 2$ & -17.7 & -17.6 & -0.1 & 10.1 & 10.8 & -0.7 & Weaned \\
\hline JOS 17 & $3.1-3.5$ & $\mathrm{dm} 2$ & -17.3 & -17.5 & 0.2 & 11.2 & 10.9 & 0.3 & ND \\
\hline JOS 18 & $3.4-3.8$ & $\operatorname{dm} 2$ & -18.1 & -18.5 & 0.4 & 10.6 & 10.5 & 0.1 & ND \\
\hline JOS 20 & $4.8-5.6$ & M1 & -18.1 & -18.1 & 0.0 & 10.5 & 9.9 & 0.6 & $e^{\mathrm{e}}$ \\
\hline
\end{tabular}

a JOS, Josefov; MIK, Mikulčice.

${ }^{\mathrm{b}} \mathrm{di} 1$, di2 = first, second deciduous incisor; dc = deciduous canine; dm1, dm2 = first, second deciduous molar; M1 = first permanent molar.

${ }^{\mathrm{c}}$ Relative difference between tooth and bone; significant $(> \pm 0.4)$ differences in bold font.

${ }^{\mathrm{d}}$ Based on $\Delta{ }^{15} \mathrm{Nt}-\mathrm{b}$; ND, no significant isotopic difference.

${ }^{\mathrm{e}}$ In the case of JOS 20, the feeding status was not estimated due to its unexpected isotopic values (for more details see Results and Discussion).

Stable nitrogen isotopes. Based on the criteria described earlier $\left(\Delta^{15} \mathrm{Nt}-\mathrm{b}> \pm 0.4\right)$, the feeding status was estimated in 25 cases (14 urban, 11 rural) of a total number of 41 individuals (Table 2). These results reveal a great variability in the age of dietary change within the Great Moravian population.

In the rural population sample of Josefov, nearly all children under 2 years (using the median dental age) had a $\Delta^{15} \mathrm{Nt}$-b value higher than $0.4 \%$, which suggests that they were breastfed substantially (Fig. 2). During the third year of life a strong decrease in the $\Delta^{15} \mathrm{Nt}-\mathrm{b}$ value was observed. The youngest children were weaned at this age, while some others were still consuming a substantial proportion of breast milk. Due to the low number of individuals aged between 3 and 5 years, we were not able to distinguish when exactly the process of weaning was completed among this rural community.
However, $\Delta^{15} \mathrm{Nt}-\mathrm{b}$ data from the Josefov sample showed one clear pattern of weaning, beginning after the age of 2 and completed probably during the fourth year of life.

The only exception from this trend is represented by the oldest individual from the entire sample (JOS20, aged $4.8-5.6$ years), whose $\Delta^{15} \mathrm{Nt}-\mathrm{b}$ value corresponds to a diet substantially based on breast milk. This is highly unlikely, taking into account the age of JOS20 as well as the fact that its $\delta^{15} \mathrm{~N}$ value were some of the lowest in the whole sample (the lowest in bone). Potential causes of these unexpected values will be discussed later. However, this outlier was excluded from the statistical analysis (Fig. 2).

In the urban sample of Mikulčice, greater variability in children's' diet was observed. The youngest children were weaned during their second year of life. And, according to the isotopic results, some others may have 

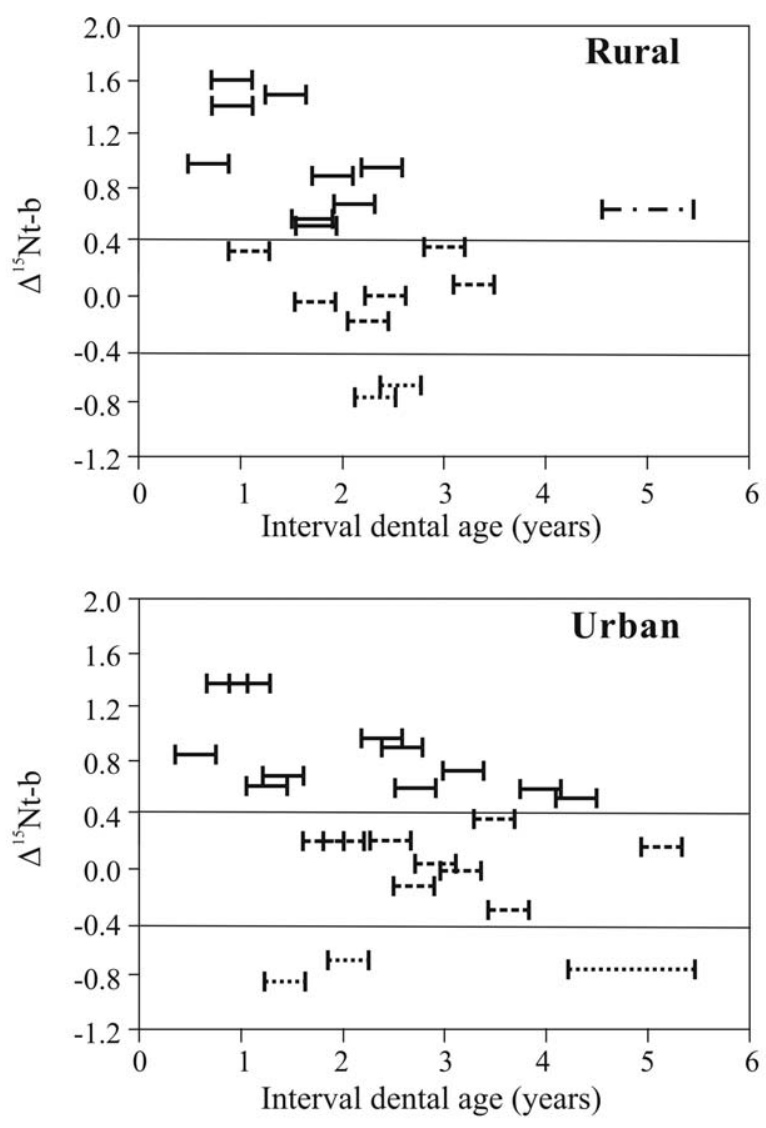

$\longmapsto$ Breastfed $\vdash-\boldsymbol{l} \begin{aligned} & \text { No significant isotopic } \\ & \text { difference }\end{aligned}$

Fig. 2. Relative nitrogen isotopic differences between the tooth dentin and bone samples $\left(\Delta^{15} \mathrm{Nt}\right.$-b) in the rural (Josefov) and urban (Mikulčice) part of the Great Moravian population. $\Delta^{15} \mathrm{Nt}-\mathrm{b}>0.4$ interpreted as breastfed, $\Delta^{15} \mathrm{Nt}-\mathrm{b}<-0.4$ interpreted as weaned, $\Delta^{15} \mathrm{Nt}-\mathrm{b} \in[-0.4,0.4]$ interpreted as undetermined feeding status; age $=$ median dental age in years.

still been consuming breast milk substantially at the age of 4 years (Fig. 2). This prolonged period of substantial consumption of breast milk in a portion of a population is surprising but not exceptional. In studies of both archaeological evidence (Herrscher, 2003, 2005; WatersRist et al., 2011) and current practices (Moffat, 2001; Sellen, 2001; Simondon et al., 2001; Kennedy, 2005), populations could be found with examples of prolonged breastfeeding during the third or fourth year of life. In some cases, the age at complete cessation of breastfeeding was reported to be more than 6 years (Dettwyler, 2004). Also historical sources mention examples of populations where the age of weaning (at least the recommended) was as high as three or even 6 years (Fildes, 1995; Piovanetti, 2001).

Stable carbon isotopes. According to Fuller et al. (2006) a slight trophic level effect in $\delta^{13} \mathrm{C}$ values $(+1 \%)$ is also observable in breastfed infants. Subsequently, during weaning, carbon isotopic values show a more rapid decrease to the adult mean than $\delta^{15} \mathrm{~N}$ values, which led Fuller et al. (2006) to declare $\delta^{13} \mathrm{C}$ to be a good indicator for detection of the first introduction of

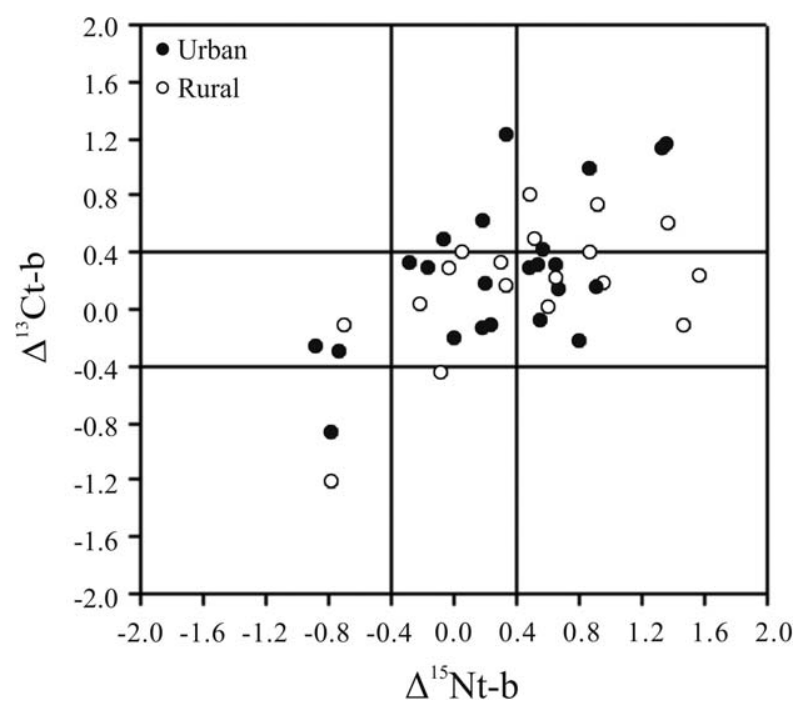

Fig. 3. $\Delta^{13} \mathrm{Ct}-\mathrm{b}$ in relation to $\Delta^{15} \mathrm{Nt}-\mathrm{b}$ in the rural (Josefov) and urban (Mikulčice) parts of the Great Moravian population.

supplementary food into a diet. In our sample, however, we do not see any clear pattern of decreasing $\Delta^{13} \mathrm{Ct}$-b, which could be attributed to weaning. In some cases, the values were more positive or negative $( \pm 1.2 \%$ ) than is generally attributed to the trophic level effect of exclusive breastfeeding (Fig. 3). These results suggest the existence of others factors that could play a role in carbon isotopic variability in our sample of Great Moravian children. From the individual values, the most interesting is a group of children $(N=3$, all coming from the urban context) with highly increased $\Delta^{13} \mathrm{Ct}-\mathrm{b}$, which would be consistent with exclusive breastfeeding. However, a non-significant $\Delta^{15} \mathrm{Nt}$-b value for these children precludes such an interpretation. This shift in $\Delta^{13} \mathrm{Ct}-\mathrm{b}$ may reflect the introduction of a new ${ }^{13} \mathrm{C}$ enriched food source into the diet of these children. This new dietary item was introduced into a diet of a portion of the Great Moravian population between 2 and 4 years of age, and was probably based on millet or on the milk of animals fed with it.

In the related literature, the absence of any evidence of a trophic level shift in $\delta^{13} \mathrm{C}$ attributable to lactation is quite common (e.g., Herrscher, 2003; Waters-Rist et al., 2011; Howcroft et al., 2014). Other studies were inconclusive (Dupras and Tocheri, 2007; Eerkens et al., 2011; Howcroft et al., 2012; Haydock et al., 2013), often with some individuals supporting and others contradicting this scenario. Use of isotopically distinct weaning foods (such as those based on $\mathrm{C}_{4}$ plants), or alternatively, annual or seasonal variation in the carbon isotopic composition of the mothers' diet, and therefore of breastmilk, could blur a small trophic level effect of lactation in $\delta^{13} \mathrm{C}$.

\section{Intra-population variability in feeding practices}

Multiple logistic regression analysis was used to evaluate the relationship between the breastfed/weaned status and the type of residency adjusted by age (Table 3). No significant association appears between the breastfed/weaned status and residency $(P=0.902)$. These results suggest that there were not any norms for the optimal duration of breastfeeding applied specifically 
TABLE 3. Factors associated with the weaned status (vs. breastfed status): simple and multiple logistic regressions ${ }^{a}$

\begin{tabular}{|c|c|c|c|c|c|c|c|c|c|}
\hline \multirow{2}{*}{\multicolumn{2}{|c|}{ Explanatory variables }} & \multirow[b]{2}{*}{$\mathrm{N}$} & \multicolumn{3}{|c|}{ Simple regression } & \multicolumn{4}{|c|}{ Multiple regression } \\
\hline & & & OR & $95 \% \mathrm{CI}$ & $P$ Wald & Adjusted OR & $95 \% \mathrm{CI}$ & $P$ Wald & $P$ Interaction $^{\mathrm{b}}$ \\
\hline \multirow[t]{2}{*}{ Type of residency } & Urban & 14 & 1.00 & & & 1.00 & & & \multirow[t]{3}{*}{0.284} \\
\hline & Rural & 11 & 0.82 & $0.11-5.99$ & 0.841 & 1.15 & $0.13-10.12$ & 0.902 & \\
\hline Age, (continuous) & & 25 & 1.83 & $0.81-4.65$ & 0.134 & 1.86 & $0.70-4.92$ & 0.211 & \\
\hline
\end{tabular}

${ }^{\text {a }}$ OR, odds ratio; CI, confidence interval; $P, P$-value.

${ }^{\mathrm{b}} \mathrm{p}$ Wald of the interaction age * type of residency.
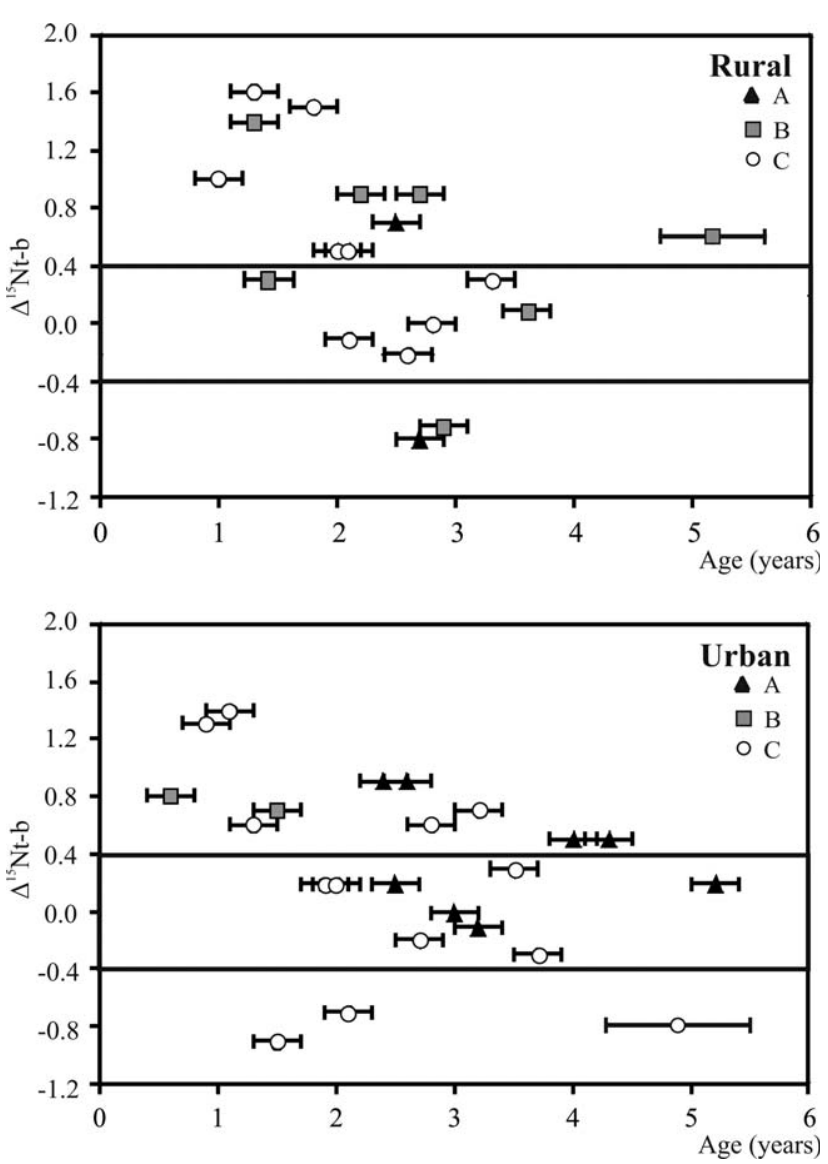

Fig. 4. $\Delta^{15} \mathrm{Nt}$-b according to the grave goods in the rural (Josefov) and urban (Mikulčice) part of Great Moravian population. $\mathbf{A}=$ graves with weapons, gold, silver or bronze objects; $\mathbf{B}$ $=$ graves with objects of daily use; $\mathbf{C}=$ without grave goods.

in urban or rural populations. However, from a biological point of view, the greater variability in weaning behavior observed in the urban sample is a notable phenomenon.

The greater diversity in the duration of breastfeeding, observed especially in the urban sample, could have several causes. First, because of the role of Mikulčice as an important center of Christianity (Poláček, 2008), Christian rules may have been adopted more quickly and the pressure to abide by them could be higher in Mikulčice, in comparison with the rural areas. These new rules and taboos clearly influenced family life and child care (Thorvaldsen, 2008). For example, the 9th century dated document The Responses of Pope Nicholas I to the Questions of the Bulgars (dated 866) recommends sexual abstinence during the entire period of breastfeeding
(Bartoňková et al., 1971). The influence of these new prescriptions could lead at least some women in Mikulčice to the abandonment of the established norm when the weaning of their children was at issue. Nonetheless, the above-mentioned document does not specify any recommendations for duration of breastfeeding (Bartoňková et al., 1971). If there were any rules postulated by the church in the Great Moravian context, they remain completely unknown to us.

Second, even if no direct information on residential mobility in the Great Moravian population is available, looking at the character of the Mikulčice settlement as well as historical circumstances (Poláček, 2008), we can suppose some level of immigration. The retention of traditional infant feeding practices in migrating families is documented by historical sources (from industrializing or industrialized populations) even despite basic changes in living conditions, which these families must have faced (Fildes, 1995). So, the presence of potential "nonlocals" adhering to the infant feeding practices traditional in their place of origin could have contributed to the observed diversity.

Third, despite the assumption that the studied area of the acropolis is a residential area of the privileged class, the cemeteries were probably used by members of the middle and lower society as well (Bigoni et al., 2013). These socio-economically distinct groups within the Mikulčice population could apply different weaning strategies. In fact, both of the individuals who were still breastfed substantially by the age $4-5$ are believed to be of high socio-economic status, based on their rich grave goods with metal objects, including gold jewelry. By contrast, the children that were weaned before the age of 2 were buried without any grave goods. On the other hand, the rural sample shows no evidence of any relationship between diet and social status (Fig. 4). However, to perform the statistical analysis of potential socio-economic differences, more individuals would have to be sampled. Moreover, when considering the effect of socio-economic status on the age of weaning, we have to keep in mind: 1) the impact of the age factor, because the presence as well as number and luxury of grave goods correlates with the age at death (Stloukal, 1970); and 2) differences in the grave goods ("richness") need not only reflect different social conditions of the respective individuals, but also, for example, different degrees of Christianization. It is probable that the proportion of pre-Christian customs, including the burial of gifts with the dead, receded during the 9th century under the influence of Church prohibition (Poláček, 2008).

And finally while environmental context as well as cultural beliefs about breastfeeding are relevant, the individual decision of mothers to wean could be modified by a number reasons specific for each case: bad health of the mother, onset of the next pregnancy, problems with 

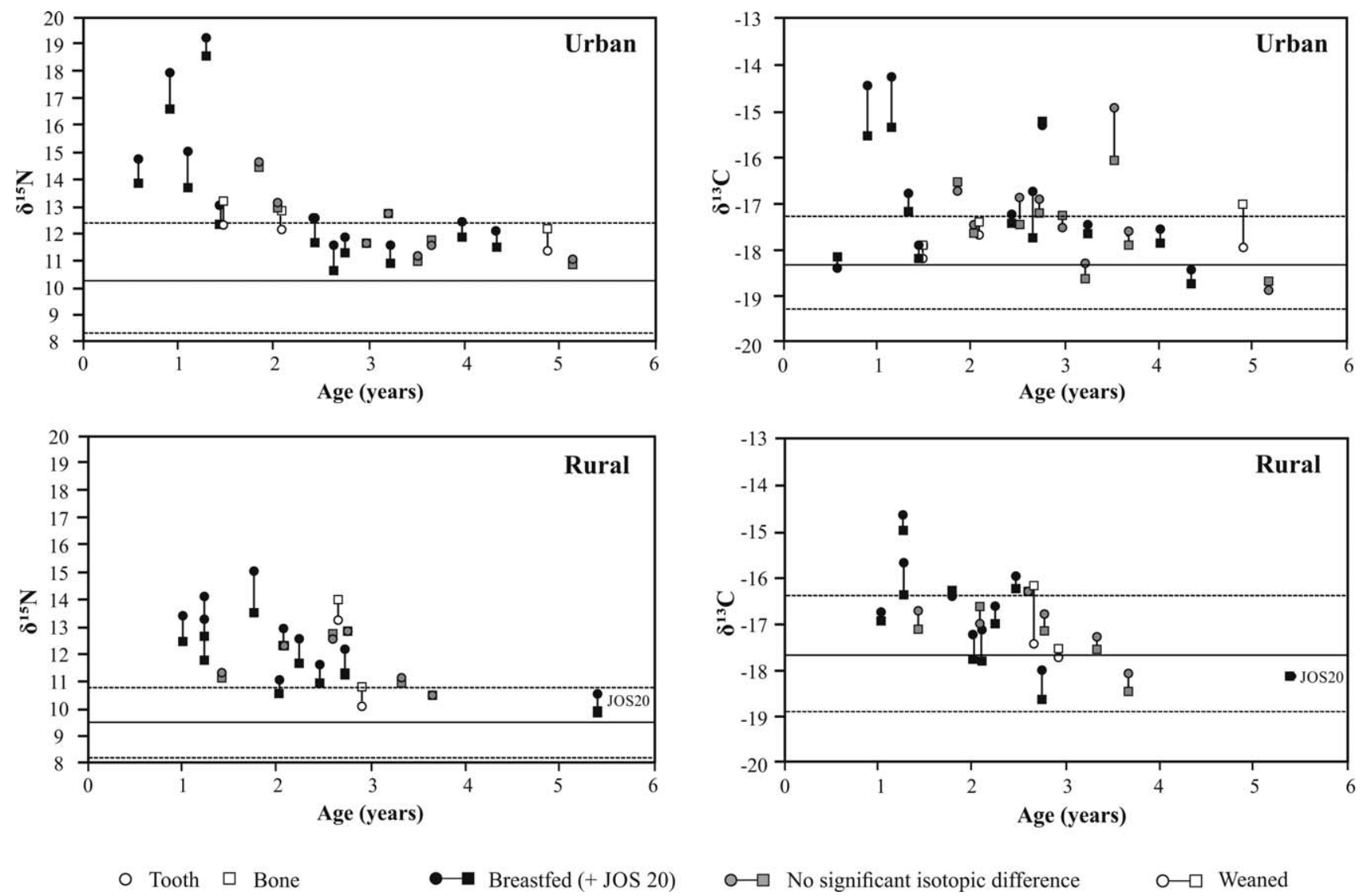

$\square$ No significant isotopic difference $\quad \square$ Weaned

Fig. 5. The $\delta^{15} \mathrm{~N}$ and $\delta^{13} \mathrm{C}$ values of subadult individuals plotted against the age at death and according to whether the sample was derived from bone or dentine. The three horizontal lines represent the adult female mean (solid line) and two standard deviations above and below this mean (dashed lines). Individual JOS20 (discussed in the text) is labeled.

TABLE 4. Age distribution and prevalence of stress indicators by age category

\begin{tabular}{|c|c|c|c|c|c|c|c|c|}
\hline \multirow[b]{2}{*}{ Age $^{\mathrm{a}}$ (years) } & \multicolumn{2}{|c|}{ Age distribution } & \multicolumn{2}{|c|}{ Cribra orbitalia $^{\mathrm{b}}$} & \multicolumn{2}{|c|}{ Porotic hyperostosis ${ }^{b}$} & \multicolumn{2}{|c|}{ Endocranial lesions ${ }^{c}$} \\
\hline & Urban & Rural & Urban & Rural & Urban & Rural & Urban & Rural \\
\hline $0.0-2.0$ & 52 & 56 & $16(6) / 38$ & $9(1) / 15$ & $7(2) / 23$ & $1(0) / 12$ & $15 / 32(12 / 22)$ & $9 / 16(6 / 11)$ \\
\hline 2.1-4.0 & 53 & 46 & $23(7) / 31$ & $14(4) / 19$ & $3(3) / 24$ & $1(0) / 11$ & $6 / 30$ & $5 / 14$ \\
\hline 4.1-6.0 & 11 & 9 & $1(0) / 6$ & $4(1) / 6$ & $0(0) / 5$ & $0(0) / 4$ & $1 / 7$ & $0 / 4$ \\
\hline Subadults & 28 & 47 & $5(2) / 8$ & $5(3) / 7$ & $0(0) / 2$ & $0(0) / 2$ & $2 / 6$ & $2 / 7$ \\
\hline Total & 144 & 158 & $45(15) / 83$ & $32(9) / 47$ & $10(5) / 54$ & $2(0) / 29$ & 24/75 (21/65) & $16 / 41(13 / 36)$ \\
\hline \multicolumn{3}{|c|}{ First occurence ${ }^{\mathrm{d}}$} & $1.0(1.0)$ & $0.8(1.4)$ & $1.0(1.3)$ & $1.2(-)$ & 0.9 & 0.8 \\
\hline
\end{tabular}

${ }^{a}$ For the purposes of sample description the individuals were divided into age groups. Individuals without recovered teeth, whose age could be estimated using growth and skeletal maturity (Stloukal and Hanakova, 1978; Scheuer and Black, 2000) were classified as subadults $(0.0-6.0)$ without further specification.

${ }^{\mathrm{b}}$ No. of cases with present lesion (Grade b $+\mathrm{c}$ in parentheses)/number of individuals with bone element present.

${ }^{\mathrm{c}}$ Number of cases with present lesion/number of individuals with bone element present (older than 1 year in parentheses).

${ }^{\mathrm{d}}$ Age of the youngest child with observed lesion (years); in the case of cribra orbitalia and porotic hyperstosis Grade $\mathrm{b}+\mathrm{c}$ in parentheses.

breastfeeding and infant suckling, mother's assessments of their children's nutritional needs, and economic or subsistence needs requiring the mother to return to work, are only some of the reasons that could motivate women to wean contrary to the generally accepted norm (Panter-Brick, 1992; Gray, 1995; Moffat, 2001; Simondon et al., 2001). Additionally, breastfeeding is ceased abruptly in case of death of the mother (Simondon et al., 2001). By contrast, mothers tend to prolong breastfeeding when there is food shortage in the household, when they are trying to avoid another pregnancy, or when their infants are weak, malnourished or sick. The infant health status may be an extremely important factor when analyzing non-survivors (Mulder-Sibanda and Sibanda-Mulder, 1999; Sellen and Smay, 2001; Simondon et al., 2001). Moreover, there are examples from historical populations in which breast milk was regarded as a beneficial food for the sick and weak, both adults and children (Salmon, 1994). However, we do not have any indication that this practice took place in the Great 

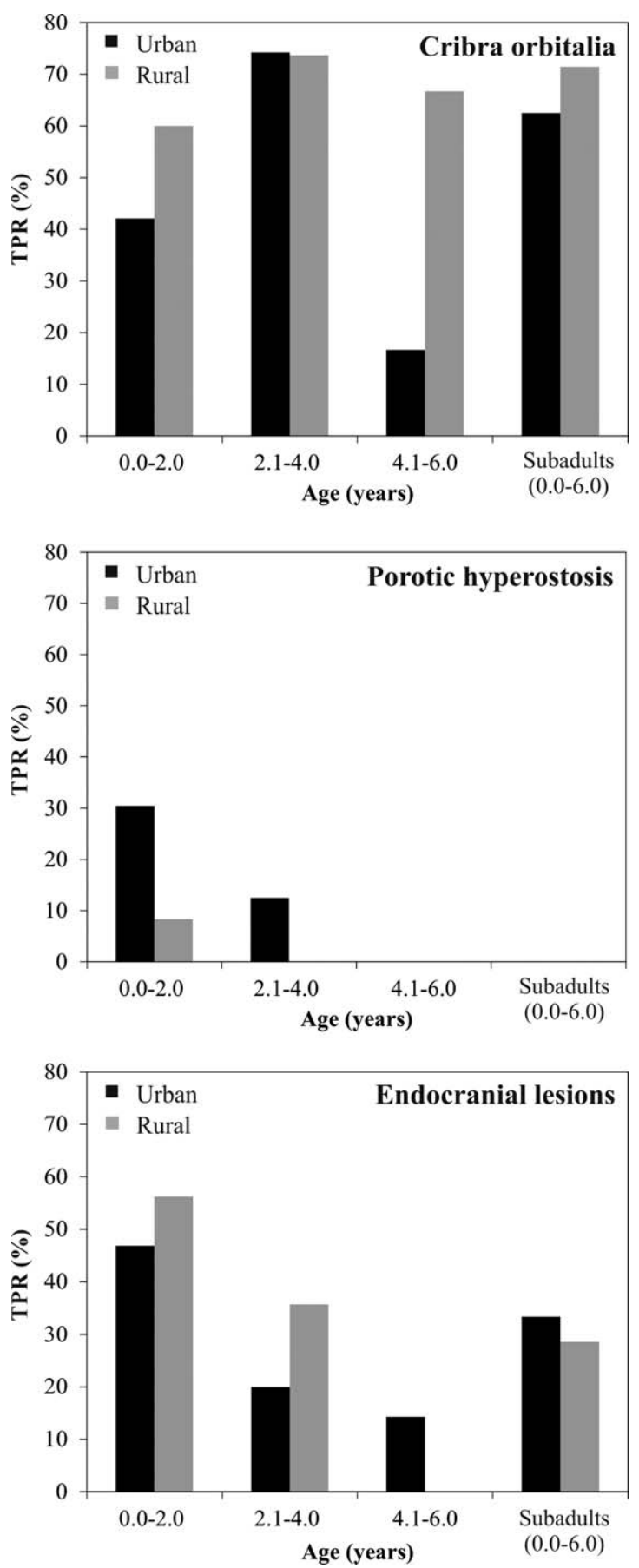

Fig. 6. True prevalence rate (TPR; \% individuals with bone element present) of stress indicators in the urban and rural sample by age category.

Moravian population and we are not sure if it was important and lasting enough to affect the isotopic values. Most of these factors are beyond our control with archaeological populations, or their evaluation would require the study of a much larger skeletal collection in an excellent state of preservation. Working on subadult populations, we were not able to consider the potential effect of the sex of the infant affecting the age of weaning through differential parental investment (Jayachandran and Kuziemko, 2011).
The main limitation of our study lies in the fact that the exact time necessary for recording of the new nutritional regime in the isotopic composition of human dental and bone tissues is not known (Herrscher, 2003). In addition, there is a lack of certainty regarding how long the metabolic nitrogen pool takes to equilibrate with the diet (Balasse et al., 2001), and the bone turnover rate in the area of the mandibular base and time required under the regime of breastfeeding to balance the $\delta^{15} \mathrm{~N}$ value in bone to those in the tooth dentine. This results in a relatively high number of individuals (15/41) whose feeding status we were not able to determine because it was impossible to be precise regarding the causes of their insignificant $\Delta^{15} \mathrm{Nt}-\mathrm{b}$.

Despite this limitation, the actual isotopic data of Great Moravians subadults, as well as those of their potential mothers (Fig. 5) still affirm the choice of the intraindividual sampling strategy. While the actual female isotopic data are going to be published elsewhere (Kaupová et al., 2014), from the view on their basic statistics $(10.28 \% \pm 1.0 \%, n=20$ for the urban sample; $9.46 \% \pm$ $0.73 \%, n=20$ for the rural sample) it is clear that the greater variability of female isotopic values (especially in the urban sample) precludes the use of the range of mean \pm 2 SD (covering $\approx 95 \%$ of female variation) as a criteria for the determination of feeding status. In the urban sample, this range is as broad as $4 \%$, which is at least equal to the full trophic level effect of exclusive breastfeeding. Accordingly, plotting $\delta^{15} \mathrm{~N}$ of dentine and/or bone samples against dental age would lead to the misinterpretation of the feeding status of children nursed by mothers with low nitrogen isotopic values, which would be erroneously determined as weaned. This would be the case, for example, for individuals MIK18 (aged 3.8-4.2 years) and MIK21 (aged 4.1-4.5 years) who-while interpreted as substantially breastfed based on $\Delta^{15} \mathrm{Nt}-\mathrm{b}$-are bordering the female group variability.

Moreover, especially in the rural population, it is not possible to observe any clear trend of decreasing $\delta^{15} \mathrm{~N}$ attributable to the weaning process: before 3 years of age, the data are highly variable. The remaining 3 (!) cases aged more than three years are located within or at least on the border of the female group variability, but they all-with the exception of JOS20 bone sample-fall within the variability of the younger group. Although the difference between younger $(<2$ years) and older (more than 2 years) individuals is more notable in the urban sample, even here we find individuals aged 2 years or less bordering the female group variability and being isotopically comparable with the older group. It is also interesting that we miss at all the children (even among those interpreted as weaned or undetermined) with isotopic values located in the lower half of female isotopic variation. This may suggest that either a certain minor proportion of their protein was still derived from breast milk or that their living conditions were more buffered with the post-weaning diet less variable in ${ }^{15} \mathrm{~N}$ and on average enriched in animal protein and/or fish, when compared with adult females (but see also the discussion concerning potential non-dietary sources of the observed variability).

For carbon, especially in the urban population sample, actual isotopic data do not reveal any trends attributable to breastfeeding and weaning behavior. This is well in accordance with conclusions derived from intraindividual results (for more details see the above discussion on carbon results). 
TABLE 5. Factors associated with the presence (vs. absence) of non-specific stress indicators: simple and multiple logistic regressions ${ }^{a}$

\begin{tabular}{|c|c|c|c|c|c|c|c|c|c|}
\hline \multirow{2}{*}{\multicolumn{2}{|c|}{ Explanatory variables }} & \multirow[b]{2}{*}{$N$} & \multicolumn{3}{|c|}{ Simple regression } & \multicolumn{4}{|c|}{ Multiple regression } \\
\hline & & & OR & $95 \% \mathrm{CI}$ & $P$ Wald & Adjusted OR* & $95 \% \mathrm{CI}$ & $P$ Wald & $P$ interaction $^{\mathrm{b}}$ \\
\hline \multicolumn{10}{|l|}{ Cribra orbitalia } \\
\hline \multirow[t]{2}{*}{ Type of residency } & Urban & 75 & 1.00 & $0.22-4.05$ & 0.145 & 1,00 & $0.79-3.97$ & 0.165 & 0.282 \\
\hline & Rural & 40 & 1.82 & & & 1.77 & & & \\
\hline Age (continuous) & & 115 & 1.17 & $0.85-1.62$ & 0.335 & 1.15 & $0.83-1.60$ & 0.394 & \\
\hline \multicolumn{10}{|l|}{ Porotic hyperostosis } \\
\hline \multirow[t]{2}{*}{ Type of residency } & Urban & 52 & 1.00 & $0.07-1.66$ & 0.181 & 1.00 & $0.06-1.62$ & 0.168 & 0.520 \\
\hline & Rural & 27 & 0.34 & & & 0.32 & & & \\
\hline Age (continuous) & & 79 & 0.62 & $0.34-1.14$ & 0.123 & 0.62 & $0.32-1.13$ & 0.117 & \\
\hline \multicolumn{10}{|l|}{ Endocranial lesions } \\
\hline \multirow[t]{2}{*}{ Type of residency } & Urban & 69 & 1.00 & $0.64-3.50$ & 0.354 & 1.00 & $0.63-3.72$ & 0.344 & 0.653 \\
\hline & Rural & 34 & 1.50 & & & 1.53 & & & \\
\hline Age (continuous) & & 103 & 0.60 & $0.40-0.89$ & 0.011 & 0.60 & $0.40-0.89$ & 0.010 & \\
\hline
\end{tabular}

${ }^{a} \mathrm{OR}$, odds ratio; $\mathrm{CI}$, confidence interval; $P, P$ value.

${ }^{\mathrm{b}} P$ Wald of the Interaction age * type of residency.

Additionally, the use of the female population mean brings another potential pitfall: Fuller and colleagues (Fuller et al., 2004, 2005) have clearly demonstrated the effect of pregnancy on isotopic data. Although little is known about the nature and extent of isotopic shifts among mothers associated with lactation (Reitsema, 2013), there are some indications from non-human animal ecology that lactation may engender stable isotope shifts in mothers as well (Jenkins et al., 2001; Polischuk et al., 2001; Kurle, 2002; Habran et al., 2010; Reitsema, 2012). Because the turnover rate of adult compact bone is quite low (Hedges et al., 2007), the bone samples reflect a mean isotopic signal for at least the last decade of individual's live (in the case of ribs). This may potentially blur any of the short term effects of either pregnancy (Nitsch et al., 2010) or lactation. Moreover, special dietary rules may be imposed on young women in different cultures in relation to their pregnancy or lactation (Baumslag, 1987). To conclude this part, we cannot be sure that the isotopic values observed in female ribs are the same as at the time they had nursed their babies, which makes the use of adult females as a comparative group disputable.

To mention the other potential limitations of our study, we also have to consider the possible interference of our results by the difference in the age composition between subsamples. In our study, the rural sample had a lower mean age (2.4 years) than the urban (2.7 years). This difference was not statistically significant (Wilcoxon test: $P=0.393$ ) and moreover all performed statistical operations controlled for the age effect. However, taking into account the low number of individuals aged 3-5 years in the Josefov sample, the potential effect of different age composition cannot be excluded.

The non-dietary factors involved in changes in $\delta^{15} \mathrm{~N}$ values recorded in tissues should also be considered. Indeed, studies conducted on adult individuals agree on the fact that physiological stress related to the protein turnover process (osteopenia, anorexia) may increase $\delta^{15} \mathrm{~N}$ values in tissues (Katzenberg and Lovell, 1999; Fuller et al., 2005; Mekota et al., 2006). For subadults, however, the impact of stress has not been fully explained. Based on the results from control feeding experiments, Ambrose (2002) proposes that while nutritional stress after maturation may occasion a tissue loss with a consecutive isotopic effect, a subadult organism undergoing a period of nutritional stress may slow their growth rate rather than resort to tissue catabolism. Kempster et al. (2007) verified that under a biologically meaningful level of nutritional stress (with the measurable impact on physiology, growth and development at multiple scales) there was no effect of the feeding regime on either $\delta^{15} \mathrm{~N}$ or $\delta^{13} \mathrm{C}$ values in any tissue of growing song sparrows. Williams et al. (2007) mention the potentially competing influence of positive nitrogen balance during growth (widely discussed by Waters-Rist and Katzenberg, 2010).

For humans, no study has yet demonstrated that enrichment in ${ }^{15} \mathrm{~N}$ in children's tissue could be related to other non-dietary factors. Two studies conducted on subadults show neither the change in $\delta^{15} \mathrm{~N}$ values during growth from early to late adolescence (Waters-Rist and Katzenberg, 2010) nor a linear correlation between $\delta^{15} \mathrm{~N}$ values for children's hair and protein metabolism (de Luca et al., 2012). On the other hand monitored studies of breastfed/bottle-fed babies and their mothers have proved the relation between ${ }^{15} \mathrm{~N}$ enrichment and breastfeeding (Fogel et al., 1989; Fuller et al., 2006).

Theoretically, some of these non-nutritional factors may well explain the aforementioned unexpected isotopic values of the JOS20 individual (4.8-5.6 years, $\Delta^{15} \mathrm{Nt}-\mathrm{b}=$ $0.6)$. However, when the health status of JOS20 was considered, this child does not appear to be stunted, and of the three evaluated nonspecific stress indicators, only cribra orbitalia was present (Figs. 7 and 8), which is absolutely insufficient (especially when taking into account the high prevalence of this pathological lesion, present in $68 \%$ of the evaluated individuals from the rural sample) to ascribe observed values unambiguously to the stress event. Additionally, this case was scored as Grade a, which according some authors (Bennike et al., 2005), is considered too mild to represent serious health problems. Alternatively this child may have increased the consumption of high trophic level food shortly before death. In the case of urban individuals that were interpreted to be still breastfed at the age of four, these alternative explanations are less probable, because their $\Delta^{15} \mathrm{Nt}-\mathrm{b}$ values were not extraordinary high but follow a general pattern in this population (Fig. 2). They are close to the level of significance, which is in accordance 
Humerus
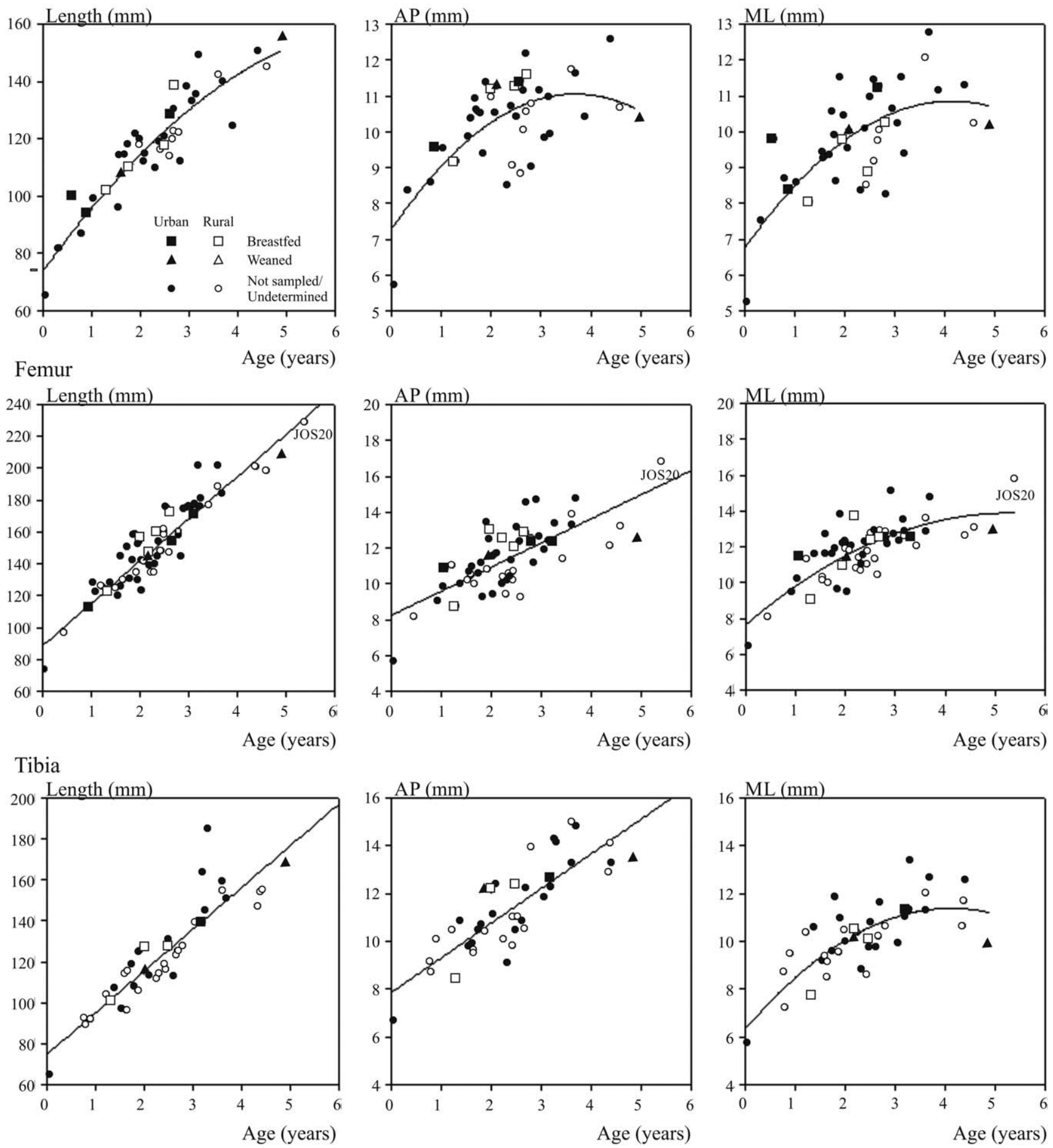

Fig. 7. Lineal regressions or second order polynomials for bone dimensions on dental age according to the urban versus rural place of residence and suggested feeding status. AP, $\mathrm{ML}=$ antero-posterior, medio-lateral diameter at the midshaft; age = median dental age in years.

with a scenario of prolonged breastfeeding, since a substantial proportion of bone had been formed under this nutritional regime. Nevertheless, low skeletal preservation precluded the osteological examination of these two individuals. Moreover, no information is available on the types of weaning food consumed by Great Moravian children. While there is wide variation exhibited between cultures in the types of supplementary foods consumed during weaning (e.g., Sellen and Smay, 2001) often including ${ }^{15} \mathrm{~N}$ highly enriched foodstuff, such as fish; the diet of Great Moravian children would have to be really specific (taking into account a central European context) in its quantity to compensate or even surpass the effect of the cessation of breastfeeding. 
TABLE 6. Regression equations for bone dimensions upon dental age

\begin{tabular}{lccc}
\hline & Length & AP & ML \\
\hline Humerus & $\mathrm{HL}=73.78+23.64$ & $\mathrm{AP}=7.26+2.05$ & $\mathrm{ML}=6.75+1.98($ age $)-0.23(\text { age })^{2}$ \\
Femur & $\mathrm{FL}=88.57+26.52($ age $)$ & AP $=8.23+1.35($ age $)$ & $\mathrm{ML}=7.63+2.38($ age $)-0.23(\text { age })^{2}$ \\
Tibia & $\mathrm{TL}=74.76+20.38($ age $)$ & $\mathrm{AP}=7.86+1.45$ (age) & $\mathrm{ML}=6.32+2.46($ age $)-0.30(\text { age })^{2}$ \\
\hline
\end{tabular}

${ }^{a} \mathrm{HL}, \mathrm{FL}$, TL, length of humerus, femur, tibia; AP, ML, antero-posterior, medio-lateral diameter at the midschaft; age, median dental age in years; all bone dimensions in $\mathrm{mm}$.

$T A B L E$ 7. The effect of type of residency on the standardized residuals of the polynomial regression on biometric measures upon dental age ${ }^{a}$

\begin{tabular}{|c|c|c|c|c|c|c|c|c|}
\hline & & \multicolumn{3}{|c|}{ Urban } & \multicolumn{3}{|c|}{ Rural } & \multirow[b]{2}{*}{$P^{\mathrm{b}}$} \\
\hline & & $N$ & Mean & s.d & $N$ & Mean & s.d. & \\
\hline \multirow[t]{3}{*}{ Humerus } & Length & 31 & 0.06 & 1.01 & 10 & -0.19 & 0.89 & 0.219 \\
\hline & $\mathrm{AP}$ & 30 & 0.10 & 0.98 & 10 & -0.31 & 0.94 & 0.268 \\
\hline & ML & 31 & 0.17 & 0.98 & 10 & -0.52 & 0.80 & 0.020 \\
\hline \multirow[t]{3}{*}{ Femur } & Length & 36 & 0.14 & 1.10 & 22 & -0.24 & 0.73 & 0.197 \\
\hline & $\mathrm{AP}$ & 36 & 0.11 & 0.98 & 22 & -0.19 & 1.01 & 0.365 \\
\hline & ML & 36 & 0.17 & 0.98 & 22 & -0.28 & 0.95 & 0.034 \\
\hline \multirow[t]{3}{*}{ Tibia } & Length & 23 & 0.19 & 1.15 & 18 & -0.24 & 0.68 & 0.293 \\
\hline & $\mathrm{AP}$ & 23 & 0.03 & 0.97 & 18 & -0.03 & 1.03 & 0.703 \\
\hline & ML & 23 & 0.14 & 1.03 & 18 & -0.19 & 0.86 & 0.287 \\
\hline
\end{tabular}

${ }^{\mathrm{a}} \mathrm{AP}, \mathrm{ML}$, antero-posterior, medio-lateral diameter at the midschaft.

${ }^{\mathrm{b}}$ Wilcoxon test for independent data.

\section{Weaning strategies in relation to health}

If one accepts weaning to be a period of a high risk of biological stress in the lives of Great Moravian children, one may suppose the above described differences in weaning strategies could result in observable differences in growth and health between an urban and rural population sample. Taking into account the isotopic results in the rural population of Josefov, one may expect a peak in mortality and incidence of stress indicators after the age of 2 years, while in the urban sample of Mikulčice more homogenous distribution of the palaeopathological data would be expected due to the higher differentiation in weaning practices, with potentially higher morbidity and mortality in the older age induced by a nutrition shortage due to prolonged breastfeeding (Pearson et al., 2010).

Comparing the prevalence of cribra orbitalia, porotic hyperostosis and endocranial lesions (see Table 4 and Fig. 6 for the prevalence and the age of the first occurrence in the sample), logistic regression analysis was used to evaluate the relation between each of the three lesions and the type of residency.

Neither the results of the simple regressions nor those of the multiple regression, adjusted on median age variable (Table 5), reveal any significant relation between the prevalence of stress indicators and the type of residency. Nonetheless, the presence of endocranial lesions is negatively associated with an increase of median age (OR $=0.60, P=0.010$ ). This means that the probability of endocranial lesion decreased when the age increased, as expected based on the results of previous studies (Lewis, 2004, 2010). However, the trend of decreasing prevalence of endocranial lesions with increasing age did not differ significantly according to the type of residency (Interaction Age * Type of residency: $P=0.653$ ). The use of alternative scoring for the presence of cribra orbitalia or exclusion of individuals younger than one year in the case of endocranial lesions did not change the results of the statistical tests significantly. In the case of porotic hyperostosis, our data did not enable repetition of the statistical test.

However, rural children seemed slightly shorter in comparison with urban children in all bone dimensions (Fig. 7), according to their age at death, the analysis of the standardized residuals of the polynomial regression (Tables 6 and 7) shows significant differences only for medio-lateral diameter of the humerus and femur (respectively, $P=$ 0.020 and $P=0.034$ ), which is not sufficient to prove any systematic and significant difference in growth between these two groups of the Great Moravian population.

Based on these results, the breastfeeding practices observed with isotope data are not reflected in the health status of both population groups. In the literature, both situations are described, either the breastfeeding duration could explain the patterns of health or mortality (Mays, 2010; Pearson et al., 2010), or there is non-causative relationship between weaning age and health and/or demographic trends in a population (Schurr, 1997; Howcroft et al., 2012), which suggests that the level of biological risk connected with the weaning varied among archaeological populations (Pearson et al., 2010). In the Great Moravian population, where the first children were weaned during the second year of life, probably a great majority of children benefited from all of the advantages of prolonged breastfeeding. By contrast, applying our sampling strategy, it is not possible to determine exactly the age of first introduction of supplementary food, which surely took place sometime before the substantial decrease in breast milk consumption, which we were able to track. This supplementary food may have protected children from potential nutritional imbalances, which could threaten the health of those that were breastfed exclusively for a long time.

And finally, two other explanations are worth mentioning. On one hand, the proportion of children weaned 

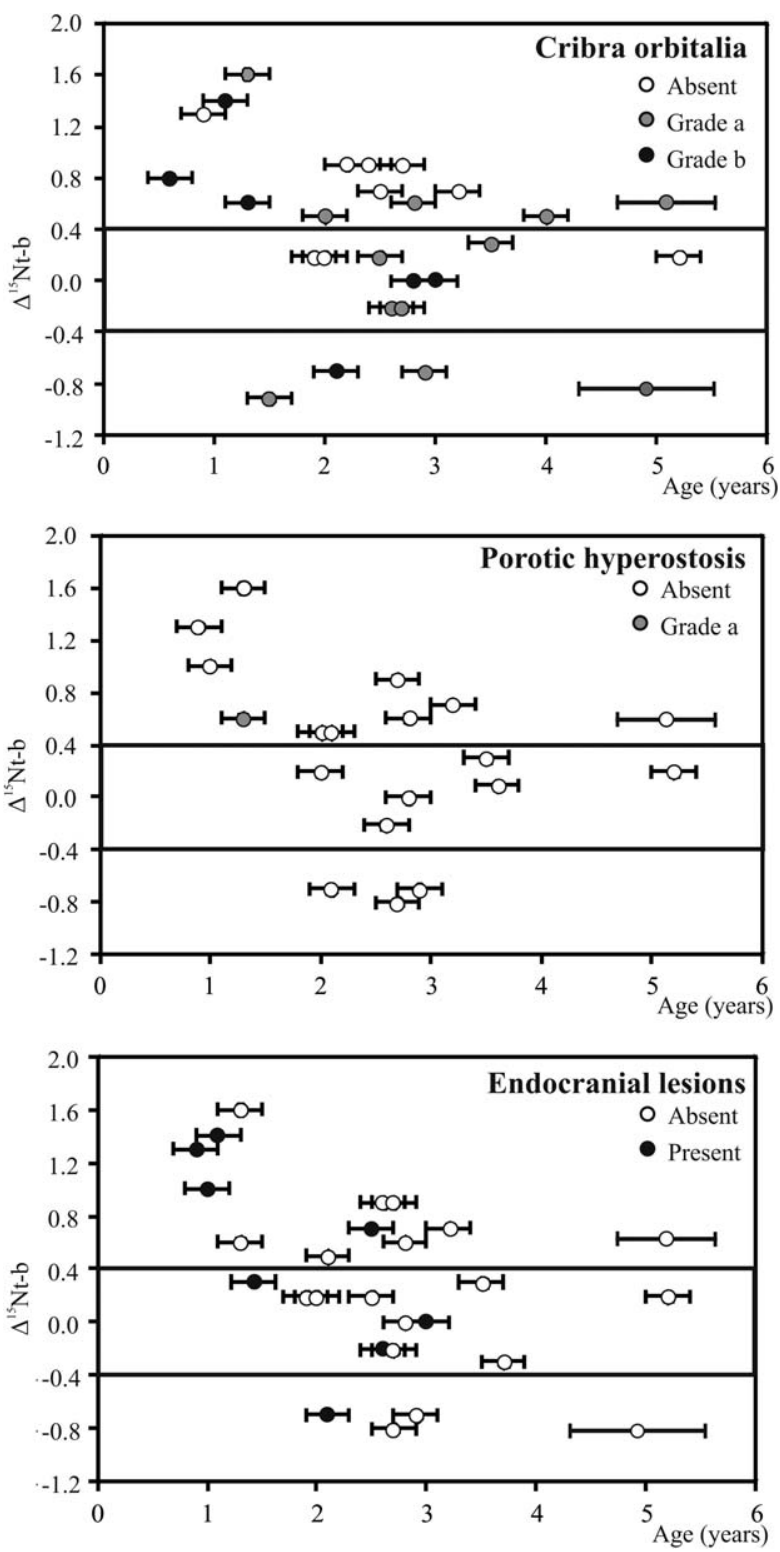

Fig. 8. $\Delta^{15} \mathrm{Nt}-\mathrm{b}$ according to the presence of non-specific stress indicators (for both urban and rural samples).

both early and late was too low to affect the general health of the urban population in comparison with a rural one, especially when taking into account the multifactorial origin of non-specific stress indicators, as well as growth faltering (Lewis, 2007). On the other hand, considering the osteological paradox (Wood et al., 1992), the recording of bone lesions consecutively to physiological stress may present a different timetable than the recording of dietary modifications due to the premature death of children.

At the individual level (Fig. 8), the low number of individuals (especially those interpreted as "weaned") and their state of preservation make the assessment of any relationship between diet and health status difficult. Cribra orbitalia were observed in all weaned children $(N$ $=4$ ), but they show a high prevalence among other groups (breastfed and undetermined) as well. When we focus solely on Grade b, affected individuals are present in all dietary groups. Porotic hyperostosis was observed just in one case (Grade a), which makes any evaluation of the relation to the dietary status impossible. Most of the cases of endocranial lesions were observed in the "breastfed" group. However, most of these cases are the youngest individuals ( $<2$ years old), where a nonpathological origin cannot be excluded (Lewis, 2004). When these individuals are not considered, the remaining four cases are again distributed among all three dietary groups. Regrettably, our data did not permit any statistical analysis. Based on these data, any of the dietary groups appears to be more buffered against biological stress. Due to the low number of "weaned" individuals with measurable bone dimensions (Fig. 7), it was impossible to describe the relationship between diet and potential stunting. For all these reasons, it is not possible to determine any relevant relation between breastfeeding practices and health status for Great Moravian children.

\section{CONCLUSION}

Analysis of dietary behaviors and health status of subadults within three archaeological sites from Great Moravian period indicated subtle patterns. One could see in our results that there was not only one norm for the duration of breastfeeding established in the Great Moravian population. Nonetheless, the data from the urban sample of Mikulčice are more variable when compared with the rural sample, with both early weaning and prolonged breastfeeding being observed. That would suggest the existence of some culturally based ideals for breastfeeding and weaning behavior. However, if these ideals existed, they were likely multiple and related to the different rates of cultural and social change in different groups in Great Moravian society. The results of our study confirm the necessity of using an intraindividual sampling strategy to detect different trends in weaning behavior within the population and to understand the relationship between social structure and the sociobiological phenomenon of weaning.

There is no evidence that observed weaning strategies affected the level of biological stress, which urban subadult population must have faced respective to rural subadult population. This finding, as well as the observation of great intra-population variability in weaning behavior observed in our sample, lead us to urge caution when interpreting child morbidity and demographic trends in past populations.

\section{ACKNOWLEDGMENTS}

This work was financially supported by the Ministry of Culture of the Czech Republic (DKRVO 2013/18 and DKRVO 2014/18, National Museum, 00023272), by the Charles University in Prague, project GA UK No. 642413 and by the French-Czech project Barrande Mobility 7AMB13FR012. We thank International Science Editing and Lauren Hosek for the English language editing. We appreciate the insightful editorial and reviewer comments on a first version of this manuscript.

\section{LITERATURE CITED}

Ambrose SH. 2002. Controlled diet and climate experiments on nitrogen isotope ratios of rats.In: Ambrose SH, Katzenberg MA, editors. Biogeochemical approaches to paleodietary analysis. New York: Springer. p 243-259. 
Ambrose SH, Norr L. 1993. Experimental evidence for the relationship of the carbon isotope ratios of whole diet and dietary protein to those of bone collagen and carbonate.In: Lambert JB, Grupe G, editors. Prehistoric human bone archaeology at the molecular level. Berlin: Springer-Verlag. p 1-37.

Baker S, Butterworth E, Langley F. 1946. Nitrogen in human infant and adult rib bones. Biochem J 40:391.

Balasse M, Bocherens H, Mariotti A. 1999. Intra-bone variability of collagen and apatite isotopic composition used as evidence of a change of diet. J Archaeol Sci 26:593-598.

Balasse M, Bocherens H, Mariotti A, Ambrose SH. 2001. Detection of dietary changes by intra-tooth carbon and nitrogen isotopic analysis: an experimental study of dentine collagen of cattle (bos taurus). J Archaeol Sci 28:235-245.

Bartoňková D, Haderka K, Havlík L, Ludvíkovský J, Vašica J, Večerka R, editors. 1971. Magnae moraviae fontes historici iv. Brno: Universita J.E. Purkyně - filosofická fakulta.

Baumslag N. 1987. Breastfeeding: cultural practices and variations.In: Jelliffe D, Jelliffe E, editors. Advances in international maternal and child health 7. Oxford: Clarendon Press. p 36-50.

Bennike P, Lewis ME, Schutkowski H, Valentin F. 2005. Comparison of child morbidity in two contrasting medieval cemeteries from Denmark. Am J Phys Anthropol 128:734-746.

Bigoni L, Krajíček V, Sládek V, Velemínský P, Velemínská J. 2013. Skull shape asymmetry and the socioeconomic structure of an early medieval Central European society. Am J Phys Anthropol 150:349-364.

Bocherens H. 1992. Biogéochimie isotopique $\left({ }^{13} \mathrm{C}{ }^{18} \mathrm{O}\right)$ et paléontologie des vertébrés: application à l'étude des réseaux trophiques révolus et des paléoenvironnements [Thèse de doctorat]. Paris: Université Paris VI.

Chisholm BS. 1989. Variation in diet reconstruction based on stable carbon isotope evidence.In: Price TD, editor. The chemistry of prehistoric bone. New York: Cambridge University Press. p 10-37.

de Luca A, Boisseau N, Tea I, Louvet I, Robins RJ, Forhan A, Charles M-A, Hankard R. 2012. $\delta^{15} \mathrm{~N}$ and $\delta^{13} \mathrm{C}$ in hair from newborn infants and their mothers: a cohort study. Pediatr Res 71:598-604.

Dean MC. 2007. A radiographic and histological study of modern human lower first permanent molar root growth during the supraosseous eruptive phase. J Hum Evol 53:635-646.

Dean MC, Vesey P. 2008. Preliminary observations on increasing root length during the eruptive phase of tooth development in modern humans and great apes. J Hum Evol 54:258 271.

Demmelmair H, von Rosen J, Koletzko B. 2006. Long-term consequences of early nutrition. Early Hum Dev 82:567-574.

DeNiro MJ. 1985. Post-mortem preservation and alteration of in vivo bone collagen isotope ratios on relation to palaeodietary reconstruction. Nature 317:806-809.

DeNiro MJ, Epstein S. 1978. Influence of diet on the distribution of carbon isotopes in animals. Geochim Cosmochim Acta 42:495-506.

DeNiro MJ, Epstein S. 1981. Influence of diet on the distribution of nitrogen isotopes in animals. Geochim Cosmochim Acta 45:341-351.

Dettwyler KA. 2004. When to wean: biological versus cultural perspectives. Clin Obstet Gynecol 47:712-723.

Dupras TL, Tocheri MW. 2007. Reconstructing infant weaning histories at roman period Kellis, Egypt using stable isotope analysis of dentition. Am J Phys Anthropol 134:63-74.

Eerkens JW, Berget AG, Bartelink EJ. 2011. Estimating weaning and early childhood diet from serial micro-samples of dentin collagen. J Archaeol Sci 38:3101-3111.

Eveleth P, Tanner J. 1990. World variation in human growth. Cambridge: Cambridge University Press.

Fewtrell MS, Morgan JB, Duggan C, Gunnlaugsson G, Hibberd PL, Lucas A, Kleinman RE. 2007. Optimal duration of exclusive breastfeeding: what is the evidence to support current recommendations? Am J Clin Nutr 85:635S-638S.

Fildes V. 1995. The culture and biology of breastfeeding: an historical review of Western Europe. In: Stuart-Macadam P,
Dettwyler KA, editors. Breastfeeding: biocultural perspective. New York: Aldine de Gruyter, Hawthorne. p 75-99.

Fogel ML, Tuross N, Owsley DW. 1989. Nitrogen isotope tracers of human lactation in modern and archaeological populations. Annual Report of Geophysical Laboratory Carnegie Institution of Washington. $\mathrm{p}$ 111-117.

Foote K, Marriott L. 2003. Weaning of infants. Arch Dis Child 88:488-492.

Fuller BT, Fuller JL, Harris DA, Hedges RE. 2006. Detection of breastfeeding and weaning in modern human infants with carbon and nitrogen stable isotope ratios. Am J Phys Anthropol 129:279-293.

Fuller BT, Fuller JL, Sage NE, Harris DA, O'Connell TC, Hedges RE. 2004. Nitrogen balance and $\delta^{15} \mathrm{~N}$ : why you're not what you eat during pregnancy. Rapid Commun Mass Spectrom 18:2889-2896.

Fuller BT, Fuller JL, Sage NE, Harris DA, O'Connell TC, Hedges RE. 2005. Nitrogen balance and $\delta 15 n$ : why you're not what you eat during nutritional stress. Rapid Commun Mass Spectrom 19:2497-2506.

Fuller BT, Richards MP, Mays SA. 2003. Stable carbon and nitrogen isotope variations in tooth dentine serial sections from Wharram Percy. J Archaeol Sci 30:1673-1684.

Garcin V, Velemínský P, Trefný P, Bagousse AA-L, Lefebvre A, Bruzek J. 2010. Dental health and lifestyle in four early Mediaeval juvenile populations: comparisons between urban and rural individuals, and between coastal and inland settlements. Homo 61:421-439.

Gowland R, Western A. 2012. Morbidity in the marshes: using spatial epidemiology to investigate skeletal evidence for malaria in Anglo-Saxon England (AD 410-1050). Am J Phys Anthropol 147:301-311.

Gray SJ. 1995. Correlates of breastfeeding frequency among nomadic pastoralists of Turkana, Kenya: a retrospective study. Am J Phys Anthropol 98:239-255.

Habran S, Debier C, Crocker DE, Houser DS, Lepoint G, Bouquegneau JM, Das K. 2010. Assessment of gestation, lactation and fasting on stable isotope ratios in northern elephant seals (Mirounga angustirostris). Mar Mamm Sci 26:880-895.

Haines MR, Kintner HJ. 2008. Can breast feeding help you in later life? Evidence from German military heights in the early 20th century. Econ Hum Biol 6:420-430.

Havelková P, Villotte S, Velemínský P, Poláček L, Dobisíková M. 2010. Enthesopathies and activity patterns in the early medieval Great Moravian population: evidence of division of labour. Int J Osteoarchaeol 21:487-504.

Haydock H, Clarke L, Craig-Atkins E, Howcroft R, Buckberry J. 2013. Weaning at anglo-saxon raunds: implications for changing breastfeeding practice in britain over two millennia. Am J Phys Anthropol 151:604-612.

Hedges R, Clement JG, David C, Thomas L, O'Connell TC. 2007. Collagen turnover in the adult femoral mid-shaft: modeled from anthropogenic radiocarbon tracer measurements. Am J Phys Anthropol 133:808-816.

Herold H. 2012. Fortified settlements of the 9th and 10th centuries ad in central Europe: structure, function and symbolism. Mediev Archaeol 56:60-84.

Herrscher E. 2003. Alimentation d'une population historique. Analyse des données isotopiques de la nécropole SaintLaurent de Grenoble (xiiie-xve siècle France). Bull Mem Soc Anthropol Paris 15:149-269.

Herrscher E. 2005. Comportements socioculturels liés à l'allaitement et au sevrage : le cas d'une population Grenobloise sous l'ancien régime. Ann Fyssen 20:46-66.

Herrscher E. 2013. Détection isotopique des modalités d'allaitement et de sevrage à partir des ossements archéologiques. Cah Nutr Diét 48:75-85.

Howcroft R, Eriksson G, Liden K. 2012. Conformity in diversity? Isotopic investigations of infant feeding practices in two iron age populations from Southern Oland, Sweden. Am J Phys Anthropol 149:217-230.

Howcroft R, Eriksson G, Lidén K. 2014. Infant feeding practices at the Pitted Ware Culture site of Ajvide, Gotland. J Anthropol Archaeol 34:42-53. 
Jayachandran S, Kuziemko I. 2011. Why do mothers breastfeed girls less than boys? Evidence and implications for child health in India. Q J Econ 126:1485-1538.

Jenkins SG, Partridge ST, Stephenson TR, Farley SD, Robbins CT. 2001. Nitrogen and carbon isotope fractionation between mothers, neonates, and nursing offspring. Oecologia 129:336341 .

Katzenberg A, Herring A, Saunders SR. 1996. Weaning and infant mortality: evaluating the skeletal evidence. Yearb Phys Anthropol 39:177-199.

Katzenberg MA, Lovell NC. 1999. Stable isotope variation in pathological bone. Int J Osteoarchaeol 9:316-324.

Kaupová S, Herrscher E, Velemínský P, Cabut S, Brůžek J. 2014. Urban and rural dietary patterns in early Medieval Central Europe $\left(9^{\text {th }}-10^{\text {th }}\right.$ century $A D$, Czech Republic). Abstract. Program of the 83rd Annual Meeting of the American Association of Physical Anthropologists. Am J Phys Anthropol 153:155.

Kempster B, Zanette L, Longstaffe F, MacDougall-Shackleton S, Wingfield J, Clinchy M. 2007. Do stable isotopes reflect nutritional stress? Results from a laboratory experiment on song sparrows. Oecologia 151:365-371.

Kennedy G. 2005. From the ape's dilemma to the weanling's dilemma: early weaning and its evolutionary context. J Hum Evol 48:123-145.

Klanica Z. 1990. K počátkům staromoravského kostrového pohřbívání.In: Galuška L, editor. Staroměstská výročí. Brno Uherské Hradiště: moravské zemské muzeum - Slovácké muzeum. p 57-64.

Klanica Z. 2006. Nechvalín, Prušánky. Čtyřri slovanská pohřebiště, díl I-II. Brno: Archeologický ústav Akademie věd Ceské Republiky.

Klíma B. 2007. Prvky pohřebního ritu na velkomoravské nekropoli v Josefově I. Sborník Prací Fil Fak Brno, řada společenských 22:3-25.

Kramer M, Kakuma R. 2009. Optimal duration of exclusive breastfeeding (review). The Cochrane Library.

Kurle CM. 2002. Stable-isotope ratios of blood components from captive northern fur seals (callorhinus ursinus) and their diet: applications for studying the foraging ecology of wild otariids. Can J Zool 80:902-909.

Lamberti LM, Fischer Walker CL, Noiman A, Victora C, Black RE. 2011. Breastfeeding and the risk for diarrhea morbidity and mortality. BMC Public Health 11 Suppl 3:S15.

Larsen CS. 1997. Bioarchaeology: interpreting behavior from the human skeleton. Cambridge: Cambridge University Press.

Lewis M. 2004. Endocranial lesions in non-adult skeletons: understanding their aetiology. Int J Osteoarchaeol 14:82-97.

Lewis ME. 2007. The bioarchaeology of children: perspectives from biological and forensic anthropology: Cambridge: Cambridge University Press.

Lewis ME. 2010. Life and death in a civitas capital: metabolic disease and trauma in the children from late Roman Dorchester, Dorset. Am J Phys Anthropol 142:405-416.

Lewis ME. 2013. Children of the Golden Minster: st. oswald's priory and the impact of industrialisation on child health. J Anthropol.

Liversidge HM, Herdeg B, Rösing F. 1998. Dental age estimation of non-adults. A review of methods and principles. In: Alt KW, Rösing FW, Teschler-Nicola M, editors. Dental anthropology: fundamentals, limits and prospects. Springer: Vienna. $p$ 420-442. http://dx.doi.org/10.1155/2013/959472.

Longin R. 1971. New method of collagen extraction for radiocarbon dating. Nature 230:241-242.

Lutter C. 1992. Recommended length of exclusive breastfeeding, age of introduction of complementary foods, and the weaning dilemma. Geneva: World Health Organization.

Macháček J. 2010. The rise of medieval towns and states in East Central Europe: early medieval centres as social and economic systems. Leiden - Boston: Koninklijke Brill NV. 562 p.

Martin DL, Armelagos GJ. 1985. Skeletal remodeling and mineralization as indicators of health: an example from prehistoric Sudanese Nubia. J Hum Evol 14:527-537.
Mays S. 2010. The effects of infant feeding practices on infant and maternal health in a medieval community. Childhood in the Past: Int J 3:63-78.

Mays S, Ives R, Brickley M. 2009. The effects of socioeconomic status on endochondral and appositional bone growth, and acquisition of cortical bone in children from 19th century Birmingham, England. Am J Phys Anthropol 140:410-416.

McDade TW. 2005. Life history, maintenance, and the early origins of immune function. Am J Hum Biol 17:81-94.

McDade TW, Worthman CM. 1998. The weanling's dilemma reconsidered: a biocultural analysis of breastfeeding ecology. J Dev Behav Pediatr 19:286-299.

Mekota AM, Grupe G, Ufer S, Cuntz U. 2006. Serial analysis of stable nitrogen and carbon isotopes in hair: monitoring starvation and recovery phases of patients suffering from anorexia nervosa. Rapid Commun Mass Spectrom 20:1604-1610.

Měřínský Z. 2006. Ceské země od příchodu slovanů po Velkou Moravu II. Praha: Libri.

Minagawa M, Wada E. 1984. Stepwise enrichment of ${ }^{15} \mathrm{~N}$ along food chain: further evidence and the relation between $\delta^{15} \mathrm{~N}$ and animal age. Geochim Cosmochim Acta 48:1135-1140.

Moffat T. 2001. A biocultural investigation of the weanling's dilemma in Kathmandu, Nepal: do universal recommendations for weaning practices make sense? J Biosoc Sci 33:321-338.

Moorrees CFA, Fanning EA, Hunt EE. 1963. Age variation of formation stages for ten permanent teeth. J Dent Res 42:1490-1502.

Mulder-Sibanda M, Sibanda-Mulder FS. 1999. Prolonged breastfeeding in Bangladesh: indicators of inadequate feeding practices or mothers' response to children's poor health? Public Health 113:65-68.

Nathan H, Haas N. 1966. On the presence of cribra orbitalia in apes and monkeys. Am J Phys Anthropol 24:351-359.

Nitsch EK, Humphrey LT, Hedges RE. 2011. Using stable isotope analysis to examine the effect of economic change on breastfeeding practices in Spitalfields, London, UK. Am J Phys Anthropol 146:619-628.

Nitsch EK, Humphrey LT, Hedges REM. 2010. The effect of parity status on $\delta^{15} \mathrm{~N}$ : looking for the "pregnancy effect" in $18^{\text {th }}$ and $19^{\text {th }}$ century London. J Archaeol Sci 37:3191-3199.

Palou A, Pico C. 2009. Leptin intake during lactation prevents obesity and affects food intake and food preferences in later life. Appetite 52:249-252.

Panter-Brick C. 1992. Women's work and child nutrition: the food intake of 0-4 year old children in rural Nepal. Ecol Food Nutr 29:11-24.

Pearson JA, Hedges RE, Molleson TI, Özbek M. 2010. Exploring the relationship between weaning and infant mortality: an isotope case study from Aşıklı Höyük and Çayönü Tepesi. Am J Phys Anthropol 143:448-457.

Piovanetti Y. 2001. Breastfeeding beyond 12 months: an historical perspective. Pediatr Clin North Am 48:199-206.

Poláček L. 2008. Great Moravia, the power centre at Mikulčice and the issue of the socioeconomic structure.In: Velemínský $\mathrm{P}$ Poláček L, editors. Studien zum Burgwall von Mikulčice VIII. Brno: Archeologický ústav Akademie věd České Republiky. p $11-44$.

Poláček L, Marek O. 1995. Die Grabungen in Mikulčice 1954 1992. Geschichte, Grabungsmethoden und Dokumentation In: Daim F, Poláček L, editors. Studien zum Burgwall von Mikulčice I. Brno: Archeologický ústav Akademie věd České Republiky. p 13-82.

Polischuk S, Hobson K, Ramsay M. 2001. Use of stable-carbon and-nitrogen isotopes to assess weaning and fasting in female polar bears and their cubs. Can J Zool 79:499-511.

Poulík J. 1970. Doklady křestanství v Mikulčicích. Sborník Národního Mus Praha, řada A - historie 24:139-144.

Poulík J. 1975. Mikulčice: sídlo a pevnost knížat Velkomoravských. Praha: Academia.

Prentice A. 1991. Breast feeding and the older infant. Acta Paediatr 80:78-88.

Prowse TL, Saunders SR, Schwarcz HP, Garnsey P, Macchiarelli R, Bondioli L. 2008. Isotopic and dental evidence for infant and young child feeding practices in an imperial Roman skeletal sample. Am J Phys Anthropol 137:294-308. 
Quinlan RJ. 2007. Human parental effort and environmental risk. Proc Biol Sci 274:121-125.

Richards MP, Mays S, Fuller BT. 2002. Stable carbon and nitrogen isotope values of bone and teeth reflect weaning age at the medieval Wharram Percy site, Yorkshire, UK. Am J Phys Anthropol 119:205-210.

Reitsema LJ. 2012. Introducing fecal stable isotope analysis in primate weaning studies. Am J Primatol 74:926-939.

Reitsema LJ. 2013. Beyond diet reconstruction: stable isotope applications to human physiology, health, and nutrition. Am J Hum Biol 25:445-456.

Salmon M. 1994. The cultural significance of breastfeeding and infant care in early modern England and America. J Soc Hist 28:247-269.

Seibel MJ. 2003. Biochemical markers of bone remodeling. Endocrinol Metab Clin North Am 32:83-113, vi-vii.

Sellen D, Smay D. 2001. Relationship between subsistence and age at weaning in "preindustrial" societies. Hum Nat 12:47-87.

Sellen DW. 2001. Comparison of infant feeding patterns reported for nonindustrial populations with current recommendations. J Nutr 131:2707-2715.

Scheuer L, Black S. 2000. Developmental juvenile osteology. New York: Academic Press.

Schoeninger MJ, De Niro MJ. 1984. Nitrogen and carbon isotopic composition of bone collagen from marine and terrestrial animals. Geochim Cosmochim Acta 48:625-639.

Schurr MR. 1997. Stable nitrogen isotopes as evidence for the age of weaning at the Angel site: comparison of isotopic and demographic measures of weaning age. J Archaeol Sci 24:919-927.

Simondon KB, Costes R, Delaunay V, Diallo A, Simondon F. 2001. Children's height, health and appetite influence mothers' weaning decisions in rural Senegal. Int J Epidemiol 30: 476-481.

Smith HB. 1991. Standards of human tooth formation and dental and dental age assessment In: Kelley MA, Larsen CS, editors. Advances in dental anthropology. New-York: Willey-Liss. p 143-163.

Stloukal M. 1970. Anthropologische Unterschiede bei Gräbern mit verschiedener Ausstattung im Gräberfeld von Mikulčice.In: Klíma B, editor. Josefu Poulikovi k šedesátinám. Brno: ČSAV. p 121-127.

Stloukal M, Hanáková H. 1978. Die Länge der Längsknochen Altslawischer Bevölkerungen unter besonderer Berücksichtigung von Wachstumsfragen. Homo 29:53-69.

Thorvaldsen G. 2008. Was there a European breastfeeding pattern? Hist Fam 13:283-295.
Trefný P, Velemínský P. 2008. Linear enamel hypoplasia in an early medieval population of Great Moravia.In: Velemínský P, Poláček L, editors. Studien zum Burgwall von Mikulčice VIII. Brno: Archeologický ústav Akademie věd České Republiky. p 141-149.

van Klinken GJ. 1999. Bone collagen quality indicators for palaeodietary and radiocarbon measurements. J Archaeol Sci 26:687-695.

Velemínský P, Dobisíková M, Stránská P, Trefný P, Likovský J. 2009. The health status of the early medieval population of Greater Moravia in relations to social and economic structures. Acta Univ Carolinae Med Monograph 156:91.

Walker PL, Bathurst RR, Richman R, Gjerdrum T, Andrushko VA. 2009. The causes of porotic hyperostosis and cribra orbitalia: a reappraisal of the iron-deficiency-anemia hypothesis. Am J Phys Anthropol 139:109-125.

Wapler U, Crubezy E, Schultz M. 2004. Is cribra orbitalia synonymous with anemia? Analysis and interpretation of cranial pathology in Sudan. Am J Phys Anthropol 123:333-339.

Waters-Rist AL, Bazaliiskii VI, Weber AW, Katzenberg MA 2011. Infant and child diet in neolithic hunter-fishergatherers from Cis-Baikal, Siberia: intra-long bone stable nitrogen and carbon isotope ratios. Am J Phys Anthropol 146: 225-241.

Waters-Rist AL, Katzenberg MA. 2010. The effect of growth on stable nitrogen isotope ratios in subadult bone collagen. Int $\mathrm{J}$ Osteoarch 20:172-191.

WHO. 2002. Expert consultation on the optimal duration of exclusive breastfeeding. Geneva: World Health Organisation.

Williams JS, White CD, Longstaffe FJ. 2005. Trophic level and macronutrient shift effects associated with the weaning process in the postclassic Maya. Am J Phys Anthropol 128:781-790.

Williams CT, Buck CL, Sears J, Kitaysky AS. 2007. Effects of nutritional restriction on nitrogen and carbon stable isotopes in growing seabirds. Oecologia 153:11-18.

Wilson W, Milner J, Bulkan J, Ehlers P. 2006. Weaning practices of the Makushi of Guyana and their relationship to infant and child mortality: a preliminary assessment of international recommendations. Am J Hum Biol 18:312-324.

Wood JW, Milner GR, Harpending HC, Weiss KM, Cohen MN Eisenberg LE, Hutchinson DL, Jankauskas R, Cesnys G, Katzenberg MA. 1992. The osteological paradox: problems of inferring prehistoric health from skeletal samples [and comments and reply]. Curr Anthropol 33:343-370.

Yovsi RD, Keller H. 2008. Breastfeeding: an adaptive process. Ethos 31:147-171. 